\title{
Amyloid Precursor Protein Dimerization and Synaptogenic Function Depend on Copper Binding to the Growth Factor- Like Domain
}

\author{
Frederik Baumkötter, ${ }^{1}$ Nadine Schmidt, ${ }^{1}$ Carolyn Vargas, ${ }^{2}$ Sandra Schilling, ${ }^{1}$ Rebecca Weber, ${ }^{1}$ Katja Wagner, ${ }^{1}$ \\ Sebastian Fiedler, ${ }^{2}$ Wilfried Klug, ${ }^{4}$ Jens Radzimanowski, ${ }^{5}$ Sebastian Nickolaus, ${ }^{3}$ Sandro Keller, ${ }^{2}$ Simone Eggert, ${ }^{1}$ \\ Klemens Wild, ${ }^{4}$ and Stefan Kins ${ }^{1}$ \\ ${ }^{1}$ Division of Human Biology and Human Genetics, ${ }^{2}$ Molecular Biophysics and ${ }^{3}$ Division of Plant Physiology, University of Kaiserslautern, D-67663 \\ Kaiserslautern, Germany, ${ }^{4}$ Heidelberg University Biochemistry Center, University of Heidelberg, D-69120 Heidelberg, Germany, and ${ }^{5}$ Unit of Virus Host \\ Cell Interactions, International Coeducational Unit 3265, Joseph Fourier University-European Molecular Biology Laboratory-National Center of Scientific \\ Research, F-38042 Grenoble, France
}

Accumulating evidence suggests that the copper-binding amyloid precursor protein (APP) has an essential synaptic function. APP synaptogenic function depends on trans-directed dimerization of the extracellular E1 domain encompassing arowth factor-like domain (GFLD) and a copper-binding domain (CuBD). Here we report the $1.75 \AA$ crystal structure of the GFLD in complex with a copper ion bound with high affinity to an extended hairpin loop at the dimerization interface. In coimmunoprecipitation assays copper binding promotes APP interaction, whereas mutations in the copper-binding sites of either the GFLD or CuBD result in a drastic reduction in APP cisorientated dimerization. We show that copper is essential and sufficient to induce trans-directed dimerization of purified APP. Furthermore, a mixed culture assay of primary neurons with HEK293 cells expressing different APP mutants revealed that APP potently promotes synaptogenesis depending on copper binding to the GFLD. Together, these findings demonstrate that copper binding to the GFLD of APP is required for APP cis-/trans-directed dimerization and APP synaptogenic function. Thus, neuronal activity or diseaseassociated changes in copper homeostasis likely go along with altered APP synaptic function.

Key words: Alzheimer's disease; amyloid precursor protein; copper; dimerization; metal homeostasis; synaptogenesis

\section{Introduction}

The amyloid precursor protein (APP) was first identified as the precursor of amyloid $\beta(\mathrm{A} \beta)$ peptides, which are derived from sequential proteolysis by $\beta$ - and $\gamma$-secretases and aggregate in the form of amyloid plaques in the course of Alzheimer's disease

\footnotetext{
Received Jan. 15, 2014; revised June 18, 2014; accepted July 9, 2014.

Author contributions: F.B., S.Ke., S.E., K.Wi., and S.Ki. designed research; F.B., N.S., C.V., S.S., R.W., K.Wa., S.F., W.K., J.R., and S.N. performed research; F.B., N.S., C.V., S.S., R.W., K.Wa., S.F., J.R., S.Ke., S.E., K.Wi., and S.Ki. analyzed data; F.B., S.Ke., K.Wi., and S.Ki. wrote the paper.

This work was supported by the Fritz Thyssen Foundation (S.Ki.) and the German Research Foundation, including the Research Group FOR1332 (S.Ki. and K.Wi.) and the Rheinland-Pfalz Foundation for Innovation (S.Ki. and S.Ke.). We thank L. Hanke for administrative support, D. Gross for excellent technical assistance, and J. Klement for help in purifying APP fusion proteins. We thank C. Tischer (European Molecular Biology Laboratory, Heidelberg, Germany) for help with cell profiler and immunocytochemical quantification analysis, J. Kopp and C. Siegmann from the crystallization platform of the Heidelberg University Biochemistry Center/Cluster of Excellence: CellNetworks for help in protein crystallization, and I. Sinning (Heidelberg University Biochemistry Center, Heidelberg, Germany) for generous support. We acknowledge the European Synchrotron Radiation Facility for providing synchrotron radiation and for assistance in using beam-lines ID23-2 and BM29. We thank A. Vest and P. Scheiffele for help with the hemisynapse assay and P. Scheiffele for providing the Neuroligin-1 CDNA.

The authors declare no competing financial interests.

Correspondence should be addressed to either of the following: Stefan Kins, Division of Human Biology and Human Genetics, University of Kaiserslautern, Erwin-Schrödinger-Straße 13, D-67663 Kaiserslautern, Germany, E-mail: s.kins@biologie.uni-kl.de; or Klemens Wild, Heidelberg University Biochemistry Center, Im Neuenheimer Feld 328, University of Heidelberg, D-69120 Heidelberg, Germany. E-mail: klemens.wild@bzh.uni-heidelberg.de. DOI:10.1523/JNEUROSCI.0180-14.2014

Copyright $\odot 2014$ the authors $\quad 0270-6474 / 14 / 3411159-14 \$ 15.00 / 0$
}

(AD) (Masters and Beyreuther, 2006). Besides the central role of $\mathrm{APP}$ in AD pathogenesis, essential physiological functions of APP in synaptic processes have been identified, including transcellular synaptic adhesion (Müller and Zheng, 2012). Moreover, APP has been identified as an essential copper-binding protein altering metal homeostasis (White et al., 1999; Maynard et al., 2002). In turn, changes in copper homeostasis as observed for AD patients have been shown to affect APP processing (Roberts et al., 2012).

Structurally, APP is a type I transmembrane protein with a short cytoplasmic tail and a large ectodomain, including copperbinding sites in its E1 (Kong et al., 2008) and E2 (Dahms et al., 2012) domains. In addition, the $\mathrm{A} \beta$ peptide can bind copper once it is cleaved from APP (Smith et al., 2007). The E1 domain can be further subdivided into a growth factor-like domain (GFLD) and a copper-binding domain (CuBD), which has been reported to reduce $\mathrm{Cu}$ (II) to $\mathrm{Cu}$ (I) (Multhaup et al., 1996), a process possibly relevant for copper transport and the production of reactive oxygen species. APP and its homologs amyloid precursors-like protein 1 (APLP1) and APLP2 are able to form homodimers and heterodimers. Besides a lateral interaction of APP in cisorientation, cell-surface APP may also interact in a trans-cellular manner (Baumkötter et al., 2012; Isbert et al., 2012; Kaden et al., 2012). cis-dimerization affects APP processing (Kaden et al., 
2008; Eggert et al., 2009; Schmidt et al., 2012), whereas interaction in trans has been reported to promote cell adhesion (Soba et al., 2005). APP knock-out mice show cognitive deficits (Müller and Zheng, 2012), and inactivation of APP on the APLP2 knockout background in either the presynaptic or postsynaptic compartment caused defects in the neuromuscular synapse, suggesting that postsynaptic APP is required for presynaptic specialization. Consistently, expression of APP in non-neuronal cells cocultured with neurons promotes presynaptic differentiation of contacting axons, similar to Neuroligin. Thus, APP has been classified as a "synaptogenic" protein, which induce presynaptic or postsynaptic differentiation when presented to axons or dendrites, respectively (Siddiqui and Craig, 2011). Remarkably, the conserved E1 domain has been identified as the major APPinteraction interface with possible contributions from the E2 domain in the presence of heparin (Wang and Ha, 2004; Lee et al., 2011). Notably, soluble APP (sAPP) liberated after ectodomain shedding of APP as well as the purified E1 domain are monomeric in solution and can dimerize in vitro only at very high concentrations or in the presence of low-molecular-weight (LMW) heparin (Gralle et al., 2006; Kaden et al., 2008; Dahms et al., 2010). Heparin binding is mediated by a disulfide-bridged hairpin loop in the GFLD [residues 95-109, in the following denoted as ligand-binding loop (LBL); Rossjohn et al., 1999], assumed to constitute a major part of the dimerization interface (Dahms et al., 2010). Notably, the copper-binding site in the $\mathrm{CuBD}$ is close to the interface, but a possible metal bridge could not be confirmed in the crystallized E1 domain dimer (Dahms et al., 2010). Here, we report a novel high-affinity copper-binding site in the LBL of the GFLD and show that copper is essential and sufficient for APP dimerization in a cis- and trans-cellular manner. Moreover, we provide evidence by using a mixed coculture assay with APP-expressing non-neuronal cells and primary neurons, that APP triggers specializations of contacting axons in a copper-dependent manner.

\section{Materials and Methods}

Crystallization, structure determination, and refinement of the GFLD. Crystals were grown by the sitting-drop method at $18^{\circ} \mathrm{C}$ by mixing equal volumes of $10 \mathrm{mg} / \mathrm{ml} \mathrm{E1}$ and reservoir containing $6 \%(\mathrm{w} / \mathrm{v})$ polyethylene glycol 3350 and 100 mM HEPES, pH 7.5. Crystals appeared within $20 \mathrm{~d}$. Diffraction data $(\lambda=0.8726 \AA)$ were measured on beam-line ID23-2 under cryogenic conditions (100 K) at the European Synchrotron Radiation Facility (ESRF) in Grenoble, France. Data were processed with iMosflm (Battye et al., 2011) and Scala (Collaborative Computational Project Number 4, 1994). The crystal structure was determined by molecular replacement using Phaser (McCoy et al., 2007) and the crystal structure of the apo (without copper) GFLD [Protein Data Bank (PDB) identification number 1mwp] as a search model. Model building and refinement were performed in Coot (Emsley et al., 2010) and PHENIX (Adams et al., 2010), respectively. Ramachandran statistics (Chen et al., 2010) show $94 \%$ of residues in the favored region and no outliers. Figures were prepared with PyMOL [DeLano, The PyMOL molecular graphics system; http://www.pymol.org (2002)].

Purification of APP E1, APP GFLD, and CuBD. For crystallization, recombinant APP E1 (amino acids $18-189$ ) was expressed as $6 \times$ Histagged fusion protein in Pichia pastoris GS115 cells using a pBLHIS-SXderived expression vector. Cells were grown in BMGY ( $1 \%$ yeast extract, $2 \%$ peptone, $100 \mathrm{~mm}$ potassium phosphate, $\mathrm{pH} 6.0,1.34 \%$ yeast nitrogen base without amino acids, $0.0004 \%$ biotin, and $1 \%$ glycerol) at $30^{\circ} \mathrm{C}$ under vigorous shaking until the culture reached log phase growth. Cells were harvested by centrifugation at $3000 \times g$ for $10 \mathrm{~min}$ and resuspended in BMMY (BMGY with $2 \%$ methanol, without glycerol). After $24 \mathrm{~h}$, cells were again sedimented, and the supernatant was loaded on a HisTrap Fast Flow affinity column (GE Healthcare). The column was washed with binding buffer (20 mm sodium phosphate, $\mathrm{pH} 7.2,150 \mathrm{~mm} \mathrm{NaCl}$, and 10 $\mathrm{mm}$ imidazole), and the protein was eluted in elution buffer $(20 \mathrm{~mm}$ sodium phosphate, $\mathrm{pH} 7.2,150 \mathrm{~mm} \mathrm{NaCl}$, and $1 \mathrm{~m}$ imidazole). The purified protein was concentrated and purified to homogeneity by gel permeation chromatography (GPC) in $20 \mathrm{~mm}$ HEPES and $150 \mathrm{~mm} \mathrm{NaCl}, \mathrm{pH}$ 7.2. Protein concentration was determined by absorbance measurements at $280 \mathrm{~nm}$, and purity of the protein was confirmed by SDS-PAGE.

For isothermal titration calorimetry (ITC) and small-angle $\mathrm{x}$-ray scattering (SAXS) measurements, the APP E1 domain (amino acids 18-189) and the mutant APP E1 domain (APP E1 ${ }^{\text {mut }}$ ) were expressed as untagged proteins in $P$. pastoris as described above. The supernatant was loaded on a Heparin High Performance affinity column (GE Healthcare) and washed with binding buffer (20 mM HEPES, pH 7.2, and $150 \mathrm{~mm} \mathrm{NaCl}$ ), and the protein was eluted in elution buffer (20 mM HEPES, pH 7.2, and $1 \mathrm{M} \mathrm{NaCl}$ ). The purified protein was concentrated and subjected to GPC as described above. Protein purity was confirmed by SDS-PAGE.

Recombinant APP GFLD (amino acids 18-123) and CuBD (amino acids 124-189) were expressed as GST-tagged fusion proteins in Escherichia coli Origami (DE3) cells using a pGEX6P-1 derived expression vector. Cells were grown at $18^{\circ} \mathrm{C}$ in $2 \times \mathrm{YT}(1.6 \%$ tryptone, $1.0 \%$ yeast extract, and $0.5 \% \mathrm{NaCl}, \mathrm{pH} 7.0$ ). At $24 \mathrm{~h}$ after induction of protein expression by $1 \mathrm{~mm}$ isopropyl- $\beta$-D-thiogalactopyranoside, cells were harvested by centrifugation at $6000 \times g$ for $15 \mathrm{~min}$. The cell pellet was resuspended in cold PBS and incubated for $30 \mathrm{~min}$ at $4^{\circ} \mathrm{C}$ with $1 \mathrm{mg} / \mathrm{ml}$ lysozyme. Cells were disrupted by sonication, and the lysate was clarified by centrifugation at $30,000 \times g$ for $1 \mathrm{~h}$ at $4^{\circ} \mathrm{C}$ and loaded on a GST affinity column (GE Healthcare). The column was washed with PBS, and the protein was eluted in elution buffer $(50 \mathrm{~mm}$ Tris, $\mathrm{pH} 8.0$, and $10 \mathrm{~mm}$ reduced glutathione). The purified protein was incubated overnight at $4^{\circ} \mathrm{C}$ with $20 \mathrm{U} / \mathrm{mg}$ PreScission protease (GE Healthcare) and again loaded on a GST affinity column. The untagged protein was concentrated and purified to homogeneity by GPC in $20 \mathrm{~mm}$ HEPES, pH 7.2, and 150 $\mathrm{mm} \mathrm{NaCl}$. Protein concentration was determined by absorbance measurements at $280 \mathrm{~nm}$, and protein purity was confirmed by SDS-PAGE.

ITC. High-sensitivity ITC was performed at $25^{\circ} \mathrm{C}$ on a MicroCal $\mathrm{iTC}_{200}$ (GE Healthcare). The injection syringe either contained $1 \mathrm{~mm}$ $\mathrm{CuCl}_{2}$ and $4 \mathrm{~mm}$ glycine, $1 \mathrm{~mm} \mathrm{ZnSO}$, or $1 \mathrm{~mm} \mathrm{FeSO}_{4}$. The protein concentration in the cell was $20 \mu \mathrm{M}$ (APP E1), $43 \mu \mathrm{M}$ (APP E1 ${ }^{\text {mut }}$ ), $14 \mu \mathrm{M}$ (GFLD), $38 \mu \mathrm{M}$ (GFLD ${ }^{\mathrm{mut}}$ ), or $13 \mu \mathrm{M}$ (CuBD) as determined by absorbance measurements using molar extinction coefficients, $\varepsilon$, of 23.2 $\mathrm{mM}^{-1} \mathrm{~cm}^{-1}$ (APP E1 and APP E1 ${ }^{\mathrm{mut}}$ ), $15.8 \mathrm{~mm}^{-1} \mathrm{~cm}^{-1}$ (APP GFLD and APP GFLD ${ }^{\text {mut }}$ ), and $8.4 \mathrm{~mm}^{-1} \mathrm{~cm}^{-1}$ (APP CuBD) at $280 \mathrm{~nm}$. Both ligand and protein solutions were prepared in HEPES buffer $(20 \mathrm{~mm}$ HEPES and $150 \mathrm{~mm} \mathrm{NaCl}, \mathrm{pH}$ 7.2). Titrations of buffer or ligand solutions into buffer served as controls. Twenty injections of $2 \mu \mathrm{l}$ each were performed at $4 \mathrm{~min}$ time intervals using a stirring speed of $1000 \mathrm{rpm}$. The first injection was excluded from analysis. Automated baseline subtraction and peak integration were accomplished with the public-domain program NITPIC (Keller et al., 2012). Thermodynamic parameters were obtained by nonlinear least-squares data fitting using an in-house program (Kemmer and Keller, 2010) and SEDPHAT (Houtman et al., 2007).

We analyzed copper binding to APP E1, CuBD, and GFLD according to a thermodynamic model describing the competitive chelation of copper by protein and glycine (Hong et al., 2008). Briefly, copper ions were first chelated with glycine before titration into the protein solution to avoid hydroxo-complex formation of copper in aqueous solutions. To extract the parameter values characterizing copper binding to the protein, we accounted for all competing and coupled equilibria present in this system. These include the following: (1) binding of free copper to glycine to form a 1:1 complex; (2) binding of this complex to a second glycine molecule to form a 1:2 complex; and (3) binding of copper to protein. Copper also binds to HEPES buffer, but this interaction has been shown to be negligible (Hatcher et al., 2008). Literature values (Martell et al., 2004) were used to account for the glycine binding equilibria.

SAXS. SAXS was performed at the ESRF beam-line BM29 in Grenoble, France. APP E1 at concentrations of $0.25 \mathrm{mg} / \mathrm{ml}(12.6 \mu \mathrm{M}), 0.5 \mathrm{mg} / \mathrm{ml}$ $(25.3 \mu \mathrm{M}), 1.0 \mathrm{mg} / \mathrm{ml}(50.5 \mu \mathrm{M})$, and $2.0 \mathrm{mg} / \mathrm{ml}(101 \mu \mathrm{M})$ dissolved in HEPES buffer was incubated either with or without a fivefold molar excess of $1 \mathrm{~mm} \mathrm{CuCl}_{2}$ with $4 \mathrm{~mm}$ glycine for $1 \mathrm{~h}$ at $4^{\circ} \mathrm{C}$. A total of $50 \mu \mathrm{l}$ of 
protein solution for each sample (and buffer) was exposed to x-rays, and scattering data were collected. Ten individual frames of $1 \mathrm{~s}$ were collected for each exposure using a Pilatus $1 \mathrm{M}$ detector (Dectris). Individual frames were processed using the software BsxCUBE, yielding individual radially averaged curves of normalized intensity versus scattering angle, $q=4 \pi \sin \theta / \lambda$. Frames were combined, excluding any data points affected by aggregation induced by radiation damage, to give the average scattering curve for each measurement. Data were processed and analyzed using the ATSAS package, as described previously (Putnam et al., 2007). The final merged scattering data was further evaluated using PRIMUS. The isotropic scattering intensity, $I(q)$, was transformed to the distance distribution function $P(r)$ using the program GNOM. For ab initio modeling of the SAXS data, 20 sets of independent models were calculated using Dammin (Svergun, 1999) and then averaged and aligned using DAMAVER.

Circular dichroism spectroscopy. Thermal unfolding of the APP E1 domain was monitored by circular dichroism (CD) spectroscopy. APP E1 in HEPES buffer (20 mM HEPES and $150 \mathrm{~mm} \mathrm{NaCl}$, pH 7.2) either without or saturated with copper was heated from $20^{\circ} \mathrm{C}$ to $90^{\circ} \mathrm{C}$, and the ellipticity $(\theta)$ at $222 \mathrm{~nm}$ was measured on a Chirascan-plus CD spectrometer (Applied Photophysics). After the experiment, the sample was cooled back to $20^{\circ} \mathrm{C}$, and the measurement was repeated to check for reversibility.

Coimmunoprecipitation. HEK293 cells were cultivated in DMEM supplemented with $10 \%$ FBS according to standard cell culture techniques. Cells were transiently cotransfected with HA-tagged full-length and myctagged full-length or mutated pcDNA3.1-APP constructs. As control, empty vector was cotransfected with myc-tagged APP constructs. Transfection with Lipofectamine 2000 (Invitrogen) was performed according to the protocol of the manufacturer. Coimmunoprecipitation (Co-IP) was performed as described previously (Soba et al., 2005). Briefly, transfected HEK293 cells were lysed in lysis buffer [50 mM Tris, pH 7.4, 150 $\mathrm{mm} \mathrm{NaCl}, 1 \% \mathrm{NP}-40$, and Complete Protease Inhibitor mix (Roche)] for $20 \mathrm{~min}$ on ice. Lysates were clarified at $16,000 \times g$ for $10 \mathrm{~min}$, and $4 \%$ of the supernatant was denatured for the direct load. The remaining supernatant was incubated for $1 \mathrm{~h}$ at $4^{\circ} \mathrm{C}$ with $10 \mu \mathrm{l}$ of protein A Sepharose beads (GE Healthcare) to reduce unspecific binding. Beads were sedimented by centrifugation at $2000 \times g$ for $1 \mathrm{~min}$, and the supernatant was incubated overnight at $4^{\circ} \mathrm{C}$ with $20 \mu \mathrm{l}$ of anti-HA agarose beads (Roche). Beads were washed three times with lysis buffer and finally denatured (IP). Samples were separated on $8 \%$ Tris/glycine gels and probed by immunoblotting for HA- and myc-tagged APP. Statistical analysis was performed with an unpaired Student's $t$ test $\left(n \geq 4 ;{ }^{*} p<0.05\right.$; ${ }^{* *} p<0.01$; $\left.{ }_{* \star *} p<0.001\right)$. Results are presented as mean \pm SEM.

For metal ion treatment, cells were incubated with the indicated amounts of glycine-complexed copper $\left(10 \mathrm{mM} \mathrm{CuCl}_{2}, 40 \mathrm{~mm}\right.$ glycine in $20 \mathrm{~mm}$ HEPES, and $150 \mathrm{~mm} \mathrm{NaCl}, \mathrm{pH} 7.2$ ), zinc ( $10 \mathrm{~mm} \mathrm{ZnSO}_{4}$ in $20 \mathrm{~mm}$ HEPES and $150 \mathrm{~mm} \mathrm{NaCl}, \mathrm{pH} 7.2)$, or iron $\left(10 \mathrm{~mm} \mathrm{FeSO}_{4}\right.$ in $20 \mathrm{~mm}$ HEPES and $150 \mathrm{~mm} \mathrm{NaCl}$, pH 7.2) for $4 \mathrm{~h}$ before cell lysis. Afterward, Co-IP was performed as described above.

Immunocytochemistry. For immunocytochemistry, HeLa cells were cultivated and transfected as described above for HEK293 cells. At $20 \mathrm{~h}$ after transfection with target cDNA, cells $(20,000)$ were seeded on $14 \mathrm{~mm}$ glass coverslips and fixed with $4 \%(\mathrm{w} / \mathrm{v})$ paraformaldehyde/saccharose in PBS and permeabilized with $0.1 \%(\mathrm{v} / \mathrm{v}) \mathrm{NP}-40$. Nonspecific sites were blocked for $1 \mathrm{~h}$ with $5 \%(\mathrm{v} / \mathrm{v})$ goat serum in PBS. Primary antibody directed against c-myc (Santa Cruz Biotechnology) was used at 1:200 dilution and detected using secondary IgG antibody conjugated to Alexa Fluor 488 (green) fluorophore. Images were taken with an Axio Observer Z.1 (Zeiss) confocal microscope.

To estimate the level of colocalization between APP and the marker peptide for ER (KDEL-mRFP (Altan-Bonnet et al., 2006), kindly provided by Bruce Snapp), the Pearson's correlation coefficient was used. Pearson's correlation coefficient $\left(r_{\mathrm{p}}\right)$ is a statistical analysis of the relationship between fluorescence intensities. An $r_{\mathrm{p}}$ value of 0 indicates no correlation, whereas an $r_{\mathrm{p}}$ value of 1 indicates complete colocalization (Bolte and Cordelières, 2006). Statistical analysis was performed with one-way factorial ANOVA and Tukey's HSD post hoc test $\left(n=3\right.$; ${ }^{*} p<$ $\left.0.05 ;{ }^{* *} p<0.01 ;{ }^{* *} p<0.001\right)$. Results are presented as mean \pm SEM.

Cell viability analysis. Cell viability was monitored by lactate dehydro- genase (LDH) release as a marker for cell death. Briefly, HEK293 cells were seeded at a density of 30,000 cells per well in a 96 multiwell plate and incubated for $4 \mathrm{~h}$ with the indicated amounts of glycine-complexed copper $\left(10 \mathrm{~mm} \mathrm{CuCl}_{2}, 40 \mathrm{~mm}\right.$ glycine in $20 \mathrm{~mm}$ HEPES, pH 7.2, and $150 \mathrm{~mm}$ $\mathrm{NaCl}$ ) in DMEM with $0.1 \%$ FCS. The release of LDH from cells was determined in the medium with CytoTox-ONE Homogeneous Membrane Integrity Assay (Promega) according to the protocol of the manufacturer. Maximal LDH release was determined in the medium after cell lysis with $9 \%(\mathrm{w} / \mathrm{v})$ Triton X-100. Results are presented as mean \pm SEM values from three independent experiments $(n=3)$.

Mixed co-culture assay. The preparation of primary cortical neurons and coculture with HEK293 cells were performed essentially as described previously (Biederer and Scheiffele, 2007). Briefly, primary cortical neurons were prepared at E14 from C57BL/6J mice. The dissected cortices were suspended in $5 \mathrm{ml}$ of trypsin-EDTA for $15 \mathrm{~min}$ at $37^{\circ} \mathrm{C}$ and subsequently washed five times with $5 \mathrm{ml}$ of HBSS supplemented with $10 \mathrm{~mm}$ HEPES. To dissociate the cells, the cortices were resuspended in HBSS supplemented with $10 \mathrm{~mm}$ HEPES and triturated with a fire-polished glass pipette. Dissociated cells were resuspended in DB1 medium [DMEM with $10 \%(\mathrm{v} / \mathrm{v})$ FCS, $0.79 \%(\mathrm{w} / \mathrm{v})$ D-glucose, and $2 \mathrm{~mm}$ glutamine] and plated onto $14 \mathrm{~mm}$ coverslips pretreated with poly-L-lysine $(20 \mu \mathrm{g} / \mathrm{ml})$ at a density of $40,000 \mathrm{cells} / \mathrm{cm}^{2}$. After $6 \mathrm{~h}$ incubation at $37^{\circ} \mathrm{C}$, the DB1 medium was replaced by NM medium [Neurobasal medium with $2 \%(\mathrm{v} / \mathrm{v})$ B-27 supplement and 2 mm glutamate].

At $6 \mathrm{~d}$ in vitro of the neuronal culture, HEK293 cells were transiently transfected with GFP, HA-tagged Neuroligin, full-length APP (APP FL), APP $\Delta$ E1, APP H108/110A (GFLD $\left.{ }^{\text {mut }}\right)$, APP H147/151A (CuBD $\left.{ }^{\text {mut }}\right)$, or myc-tagged APP $\triangle$ EC. After $24 \mathrm{~h}$, transfected cells were detached and seeded at a density of 17,500 cells $/ \mathrm{cm}^{2}$ to the cortical culture. Twentyfour hours later, cultures were fixed in $4 \%$ (w/v) PFA supplemented with $4 \%(\mathrm{w} / \mathrm{v})$ sucrose and stained with an anti-Synaptophysin antibody (1: 200; Sigma), anti-synaptic vesicle protein 2 (SV2) antibody (1:400; Developmental Studies Hybridoma Bank), or anti-Synapsin-1 antibody (1: 5000; SYSY), all followed by an Alexa Fluor 594-conjugated secondary antibody (1:400; Invitrogen). Cells were costained with an antimicrotubule-associated protein 2 (MAP2) antibody (1:300; Santa Cruz Biotechnology), as well as anti-c-myc (1:200,; Serotec) and anti-HA (1: 300; Santa Cruz Biotechnology) antibodies to detect dendrites and the heterologously expressed proteins, respectively. In addition, cells were costained with an anti-Tau antibody (TAU-1 1:200; Millipore Bioscience Research Reagents) to detect axons. Synapses were identified as Synaptophysin-positive puncta at sites of cell contacts between neurons and HEK293 cells that do not colocalize with MAP2-positive dendritic structures. Images were taken with an Axio Observer Z.1 (Zeiss) confocal microscope, and quantification was performed via NIH ImageJ analysis. Statistical analysis was performed with one-way factorial ANOVA and Tukey's HSD post hoc test $\left(n \geq 4 ;{ }^{*} p<0.05 ;{ }^{* *} p<0.01 ;{ }^{* * *} p<0.001\right)$. Results are presented as mean \pm SEM.

Generation and purification of APPex- $F_{C}$. COS7 cells stably transfected with the ectodomain of APP (APPex; amino acids 18-624) fused to the crystallizable fragment $\left(\mathrm{F}_{\mathrm{C}}\right)$ of human IgG1 at the $\mathrm{C}$ terminus were cultivated at $37^{\circ} \mathrm{C}$ in growth medium (DMEM supplemented with $10 \%$ FCS, $1 \%$ penicillin/streptomycin, and $300 \mu \mathrm{g} / \mathrm{ml}$ hygromycin B) in a humidified atmosphere with $5 \% \mathrm{CO}_{2}$ according to standard cell culture techniques. Three days after passaging, conditioned medium was collected and centrifuged at $3000 \times g$ at room temperature for $5 \mathrm{~min}$ to clarify them from cell debris. The supernatant was filtered $(0.22 \mu \mathrm{m})$ and loaded on a recombinant protein A Sepharose FF $20 \mathrm{ml}$ affinity column (GE Healthcare). The column was washed with binding buffer $(50 \mathrm{~mm}$ Tris/ $\mathrm{HCl}$ and $300 \mathrm{~mm} \mathrm{NaCl}, \mathrm{pH}$ 7.4) until UV absorption reached baseline. The protein was eluted with $100 \mathrm{~mm}$ glycine, $\mathrm{pH}$ 2.5. To restore the $\mathrm{pH}, 100 \mu \mathrm{l}$ of $1 \mathrm{~m}$ Tris/ $\mathrm{HCl}, \mathrm{pH} 8.0$, were added immediately to the protein. The protein was concentrated and desalted with a PD-10 desalting column (GE Healthcare). Afterward, the protein was loaded on a HiTrap Heparin HP $5 \mathrm{ml}$ affinity column (GE Healthcare). The column was washed with binding buffer (20 mM HEPES and $150 \mathrm{NaCl}, \mathrm{pH} 7.2)$ until UV absorption reached baseline, and the protein was subsequently eluted with elution buffer ( $20 \mathrm{~mm}$ HEPES and $1 \mathrm{~m} \mathrm{NaCl}, \mathrm{pH}$ 7.2). Protein concentration was determined by absorbance measurements at $280 \mathrm{~nm}$ 
A

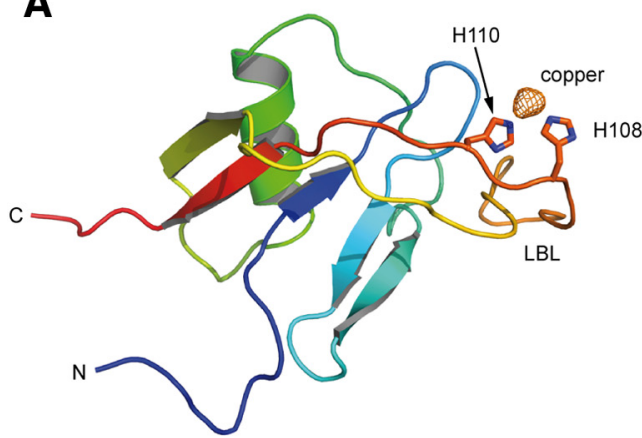

D

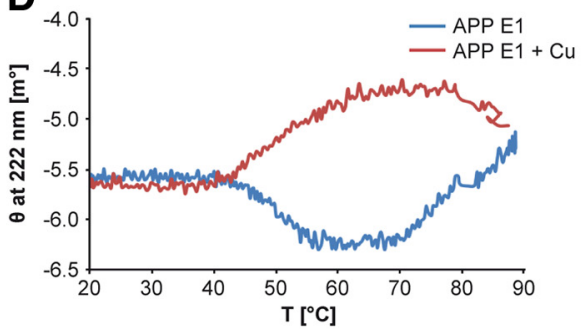

B

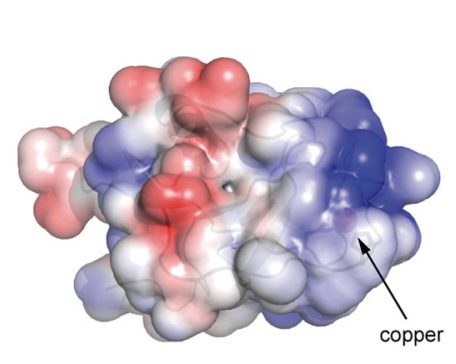

C

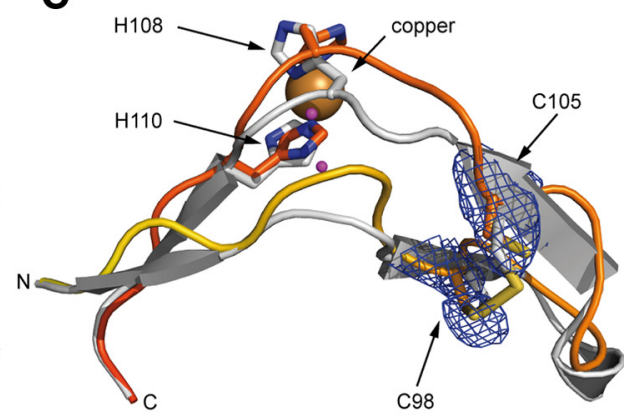

E

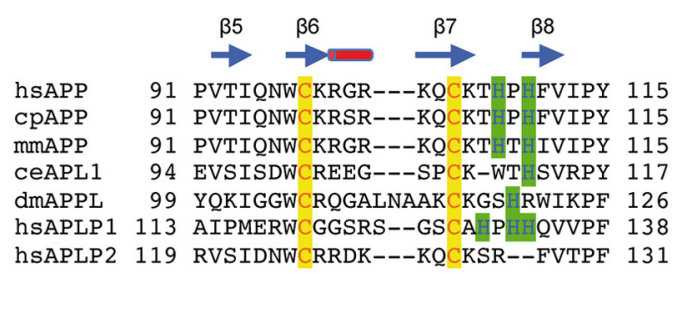

$\mathbf{F}$

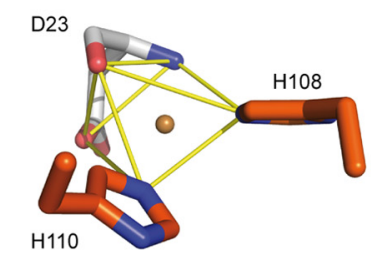

Figure 1. Copper binding to the GFLD. A, Crystal structure of the GFLD in complex with copper in a color ramp from the $\mathrm{N}$ terminus (amino acid 28; blue) to the C terminus (amino acid 189; red). The N-terminal $6 \times$ His tag is not included in the diagram representation. The anomalous difference map for the copper ion $(11.3 \sigma)$ and coordinating histidine residues $\mathrm{H} 108$ and $\mathrm{H} 110$ within the LBL (yellow-orange) are shown. B, Electrostatic surface potential ( $3 \mathrm{kT}$ ) around the copper-binding site (arrow); hydrophobic (gray) and positively (blue) or negatively (red) charged surface patches are indicated. C, Superposition of the LBL in the apo (gray; PDB identification number 1mwp) and copper-bound (color ramp) forms. Note the copper-induced reduced state of C98 and C105 as indicated by the final 2F0-Fc map shown at $1.0 \sigma$, the disintegration of the $\beta$-sheets, and the insertion of two stabilizing water molecules (magenta). $D$, Thermal unfolding monitored by $C D$ spectroscopy. The E1 domain without (blue) or saturated with (red) copper ions was heated from $20^{\circ} \mathrm{C}$ to $90^{\circ} \mathrm{C}$, and the ellipticity $(\theta)$ at $222 \mathrm{~nm}$ was measured. Differences in the unfolding process between copper-bound and apo $\mathrm{E} 1$ indicate that copper influences the fully reversible thermal unfolding of the E1 domain. E, Sequence alignment of the LBL from selected APP family members (hs, human; $\mathrm{cp}$, guinea pig; $\mathrm{mm}$, mouse; ce, Caenorhabditis elegans; $\mathrm{dm}$, Drosophila melanogaster). The N-terminal and C-terminal numbering of each LBL sequence is listed. Conserved cysteine residues forming the disulfide bond in the LBL are colored in yellow, and the copper-binding $\mathrm{H} \times \mathrm{H}$ motif is highlighted in green. $\boldsymbol{F}$, The copper coordination sphere. The copper ion is fivefold coordinated in a square pyramid formed by $\mathrm{H} 108$ and $\mathrm{H} 110$, as well as D23 of a symmetry-related molecule.

on a V-630 UV-VIS spectrophotometer (Jasco). Aliquots were taken during the purification process and analyzed by SDS-PAGE.

Bead aggregation assay. To analyze the dimerization properties of APP, $10 \mu \mathrm{l}$ of magnetic protein A polystyrene beads (Invitrogen) were incubated with $15 \mu \mathrm{g}$ of either purified human IgG $\mathrm{F}_{\mathrm{C}}$ (Bethyl) or APPex- $\mathrm{F}_{\mathrm{C}}$ in binding buffer (20 mM HEPES and $150 \mathrm{~mm} \mathrm{NaCl}, \mathrm{pH} 7.2)$ for $2 \mathrm{~h}$ at $4^{\circ} \mathrm{C}$ with end-over-end rotation. Afterward, the beads were washed three times with $500 \mu \mathrm{l}$ of binding buffer and sonicated to singularize. Aggregation of the protein-coated beads was performed for $2 \mathrm{~h}$ at $4^{\circ} \mathrm{C}$ in $800 \mu \mathrm{l}$ of binding buffer supplemented with $0.1 \%(\mathrm{w} / \mathrm{v}) \mathrm{BSA}$ and the indicated amounts of copper, zinc, iron, or heparin dodecasaccharide (dp12; Dextra Laboratories). For the measurement, $200 \mu \mathrm{l}$ of each sample were diluted in $10 \mathrm{ml}$ of Isotone II solution (Beckman Coulter) and inverted to mix. The number of aggregates $>10 \mu \mathrm{m}$ was counted with a Coulter Counter Z2 particle counter (Beckman Coulter; $100 \mu \mathrm{m}$ aperture tube). The number of aggregates formed was normalized to APPex- $\mathrm{F}_{\mathrm{C}}$. Error bars represent mean \pm SEM values. Statistical analysis was performed with unpaired Student's $t$ test $\left(n \geq 3 ;{ }^{*} p<0.05,{ }^{* *} p<0.01,{ }^{* *} p<0.001\right.$ compared with APPex- $\mathrm{F}_{\mathrm{C}}$ in buffer; ${ }^{\# \#} p<0.01$ compared with APPex- $\mathrm{F}_{\mathrm{C}}$ in buffer supplemented with $100 \mu \mathrm{M} \mathrm{CuCl}_{2}$ ).

GPC. For analytical GPC, either $35 \mu \mathrm{M}$ APP GFLD or $25 \mu \mathrm{M}$ APP GFLD $^{\text {mut }}$ were incubated or not with either $10 \times$ molar excess of heparin dodecasaccharide (dp12; Dextra Laboratories) or 50× molar excess of $\mathrm{CuCl}_{2}$ for $30 \mathrm{~min}$ on ice. A total of $100 \mu \mathrm{l}$ of the protein solution was loaded at a flow rate of $0.8 \mathrm{ml} / \mathrm{min}$ on a calibrated Superdex 75 10/300 GL gel permeation column (GE Healthcare). For calibration of the column, a calibration curve $\left[K_{\mathrm{AV}}\right.$ vs. log molecular weight (MW)] was prepared with protein standards (conalbumin, $M_{\mathrm{r}}$ =75,000; carbonic anhydrase, $M_{\mathrm{r}}=29,000$; ribonuclease $\mathrm{A}, M_{\mathrm{r}}=$ 13,700; aprotinin, $\left.M_{\mathrm{r}}=6500\right)$ of the LMW gel filtration calibration kit (GE Healthcare). The void volume $\left(V_{\mathrm{o}}\right)$ was determined by the elution volume $\left(V_{\mathrm{e}}\right)$ of Blue Dextran 2000.
Cellular copper uptake monitored by inductively coupled plasma-optical emission spectrometry. To determine the amount of copper taken up by cells, HEK293 cells were cultivated in growth medium (DMEM with $0.1 \%$ FCS and $1 \%$ penicillin/streptomycin) and incubated for $4 \mathrm{~h}$ with increasing amounts (1-500 $\mu \mathrm{M})$ of glycine-complexed copper $(10 \mathrm{mM}$ $\mathrm{CuCl}_{2}, 40 \mathrm{~mm}$ glycine in $20 \mathrm{~mm}$ HEPES, $\mathrm{pH} 7.2$, and $150 \mathrm{~mm} \mathrm{NaCl}$ ). Cells were washed once with PBS and lysed in lysis buffer $[50 \mathrm{~mm}$ Tris, $\mathrm{pH}$ 7.4, $150 \mathrm{~mm} \mathrm{NaCl}, 1 \% \mathrm{NP}-40$, and Complete Protease Inhibitor mix without EDTA (Roche)] for 20 min on ice. Lysates were clarified at $16,000 \times g$ for $10 \mathrm{~min}$ and digested in $3 \mathrm{ml}$ of $65 \%(\mathrm{v} / \mathrm{v}) \mathrm{HNO}_{3}$ and $1 \mathrm{ml}$ of $30 \%(\mathrm{v} / \mathrm{v}) \mathrm{H}_{2} \mathrm{O}_{2}$ in an MLS-Ethos microwave oven using a temperature step gradient with a maximum temperature of $210^{\circ} \mathrm{C}$. Samples were diluted to a final volume of $7 \mathrm{ml}$ with $\mathrm{ddH}_{2} \mathrm{O}$ and analyzed by inductively coupled plasma-optical emission spectrometry (ICP-OES) on an iCAP 6300 DUO spectrometer (Thermo Fisher Scientific). Copper was detected and quantified at $324.754 \mathrm{~nm}$. The detection limit for copper was $0.5 \mu \mathrm{g} / \mathrm{l}$. Protein concentration in cell lysates was determined by BCA assay (Sigma). Error bars represent mean \pm SEM values $(n=3)$.

\section{Results}

\section{Structure of the GFLD in complex with copper}

In our attempt to structurally and functionally characterize the dimerization properties of APP, we solved the $\mathrm{X}$-ray structure of the GFLD at a high resolution of $1.75 \AA$ (PDB identification number: 4JFN) in an unexpected copper-bound form (GFLD·Cu; Fig. 1A; Table 1). The identity of the metal ion was confirmed by its element-specific $\mathrm{x}$-ray fluorescence signal (11.3 $\sigma)$ and the anomalous difference Fourier map. The copper ion is ligated to the $\mathrm{N} \varepsilon 2$ atoms of two conserved histidine residues (H108 and H110), which are separated by a rigid proline residue 
Table 1. Data collection and refinement statistics

\begin{tabular}{lc}
\hline & GFLD·Cu \\
\hline Data collection & \\
Space group & P212121 \\
Cell dimensions & \\
$\quad a, b, c(\AA)$ & $34.05,49.07,66.16$ \\
Resolution $(\AA)^{a}$ & $30.28-1.75(1.81-1.75)$ \\
$R_{\text {sym }}$ & $6.3(42.9)$ \\
$I / \sigma l$ & $12.99(3.19)$ \\
Completeness $(\%)$ & $99.85(100.00)$ \\
Redundancy & $5.9(6.0)$ \\
Refinement & \\
Resolution $(\AA)$ & $30.28-1.75(1.81-1.75)$ \\
$n$ reflections & 11674 \\
$R_{\text {work }} / R_{\text {free }}$ & $0.1807 / 0.2303$ \\
$n$ atoms & \\
Protein/ligand/water & $826 / 7 / 52$ \\
B-factors & \\
Protein/ligand/water & $44.8 / 52.8 / 53.9$ \\
rms deviations & \\
Bond lengths $(\AA)$ & 0.007 \\
Bond angles $\left({ }^{\circ}\right)$ & 1.16 \\
\hline
\end{tabular}

Values in parentheses are for the highest resolution shell.

${ }^{a}$ Data measured on one crystal.

and are part of the LBL implicated in dimerization (Gralle et al., 2006; Kaden et al., 2008; Dahms et al., 2010). Copper binding occurs between conserved hydrophobic and basic surface patches (Fig. $1 B$ ), which are thought to be responsible for protein-protein (Kong et al., 2008) and protein-heparin (Dahms et al., 2010) interactions, respectively. The structure of GFLD $\cdot \mathrm{Cu}$ is overall highly similar to those of the apo form (PDB identification number 1mwp; rms deviation of $0.89 \AA$ for $96 \mathrm{C} \alpha$-atoms) and of the GFLD within the E1 domain (PDB identification number: $3 \mathrm{ktm}$ chain B; rms deviation of $0.93 \AA$ for $95 \mathrm{C} \alpha$-atoms), with one prominent exception, which is the long LBL forming a $\beta$-hairpin between stands $\beta 5$ and $\beta 8$ (Fig. $1 C$ ). The copper-binding histidine H108 is bulged out of the LBL hairpin, and two water molecules are placed within the bulge, thus stabilizing the copper-binding ligand sphere (Fig. 1C). Temperature factors within the LBL increase up to twice the average toward the distal end and the very tip. Strikingly, copper binding coincides with the reduction of the disulfide bridge (C98-C105) in the LBLintegral $\beta$-sheet ( $\beta 6$ and $\beta 7$; Fig. $1 C$ ), although purification and crystallization were performed under nonreducing conditions. Opening of the disulfide bridge between C98 and C105 and the conformational changes within the LBL (Fig. $1 C$ ) go along with altered thermal unfolding of the E1 domain, as shown by CD spectroscopy (Fig. 1D). Similarly, SAXS analyses of the APP E1 domain in the presence and absence of copper revealed subtle structural changes of the E1 domain during copper binding, which were obscured by the tendency for aggregation of the E1 domain, probably because of clustering via intermolecular copper binding (data not shown).

Sequence alignment of the LBL from different species and APP homologs reveals that the cysteines forming the disulfide bridge are conserved throughout the entire APP gene family, whereas the $\mathrm{H} \times \mathrm{H}$ arrangement of histidines is conserved in mammalian APP and APLP1 only (Fig. 1E). Besides the two histidines, the copper ion is coordinated by an aspartate (D23) of a symmetry-related molecule within the crystalline array, resulting in a square pyramidal ligand sphere (Fig. $1 F$ ). The fivecoordinate geometry is reminiscent of $\mathrm{Cu}$ (II) binding to the $\mathrm{CuBD}$, which is classified as a type-2 non-blue $\mathrm{Cu}$ (II) center
(Kong et al., 2008). This geometry is typical of redox activity as has been implicated for the $\mathrm{CuBD}$, in which $\mathrm{Cu}$ (II) is coordinated by three residues (H147, H151, and Y168) and two water molecules (Kong et al., 2007b).

\section{High-affinity binding of copper to the GFLD}

To verify the specificity and to quantify the affinity of copper binding, we performed ITC measurements on the E1 domain, the $\mathrm{CuBD}$, and the GFLD purified from $P$. pastoris and E. coli, respectively (Fig. $2 A, B$ ). All three constructs revealed high-affinity copper binding with apparent dissociation constants of $K_{\mathrm{D}}=7.5 \mathrm{nM}$ for E1, $K_{\mathrm{D}}=18 \mathrm{~nm}$ for the $\mathrm{CuBD}$, and $K_{\mathrm{D}}=28 \mathrm{~nm}$ for the GFLD (Fig. 2C-H; Table 2). The affinity for the CuBD is in agreement with a previous report $\left(K_{\mathrm{D}}=10 \mathrm{nM}\right.$; Hesse et al., 1994), whereas no comparable data are available for the GFLD and the entire E1 domain. The binding stoichiometry of copper to the CuBD is 1:1, whereas higher stoichiometries were observed for the GFLD and the E1 domain (Table 2). The latter might be explained by uncertainties in protein concentration, the presence of an additional copper-binding site in either the GFLD or the GFLD/CuBD interface, or redox activity and subsequent exchange of the ion. To validate binding specificity, we generated a mutant GFLD with the copper-coordinating histidines $(\mathrm{H} 108 / \mathrm{H} 110)$ replaced by alanines (GFLD ${ }^{\text {mut }}$ ), which did not bind copper (Fig. $2 G$ ), demonstrating that the two histidines represent the only copper binding site within the GFLD. To exclude the possibility of an additional copper-binding site at the interface of the subdomains, we generated a mutant E1 domain, in which the copper-coordinating histidine residues in the GFLD (H108/ $\mathrm{H} 110)$ and $\mathrm{CuBD}(\mathrm{H} 147 / \mathrm{H} 151)$ are replaced by alanines (APP E1 ${ }^{\text {mut }}$ ) and observed no copper binding (Fig. $2 H$ ), demonstrating that the E1 domain has only two copper-binding sites: one in the GFLD and one in the CuBD.

To unravel whether the APP E1 domain is also able to bind to other metal ions, we tested the binding of zinc and iron (II) by ITC. We observed only low micromolar binding affinity for zinc but no binding of iron (II) to the APP E1 domain (data not shown).

\section{Copper promotes APP dimerization in vivo}

Because the newly identified copper-binding site in the GFLD is next to the assumed APP dimerization interface (Soba et al., 2005; Kaden et al., 2008; Dahms et al., 2010), we characterized APP dimerization depending on a change of copper binding in the cellular context. Using a cell survival assay based on the release of $\mathrm{LDH}$, we first validated that treatment with different doses of copper $(50-1000 \mu \mathrm{M})$ did not affect cell viability of HEK293 cells (Fig. 3A). Afterward, we determined the amount of copper taken up by HEK 293 cells during treatment with increasing concentrations of copper (1-500 $\mu \mathrm{M}$ ) by ICP-OES (Fig. 3B). We observed a nonlinear increase in the cellular copper concentration with an initial rise during treatment with $10 \mu \mathrm{M} \mathrm{Cu}$ (II) from $15 \pm 6$ to $136 \pm 31 \mu \mathrm{g} \mathrm{Cu}$ (II)/g protein, followed by a slighter increase during exposure to $100 \mu \mathrm{M} \mathrm{Cu}$ (II) from $136 \pm 31$ to $303 \pm 52 \mu \mathrm{g}$ $\mathrm{Cu}(\mathrm{II}) / \mathrm{g}$ protein. Taking the current model of copper homeostasis into account (Lutsenko et al., 2010), our data indicate that the treated HEK293 cells first take up copper at low extracellular concentrations very efficiently but likely counteract the additional increase caused by high extracellular concentrations by active export of copper.

Then, we performed Co-IP studies with HA-tagged and myctagged human APP in the presence of different copper concentrations (Fig. 3C). As reported previously, myc-tagged APP was efficiently coimmunoprecipitated with HA-tagged APP (Soba et 
A
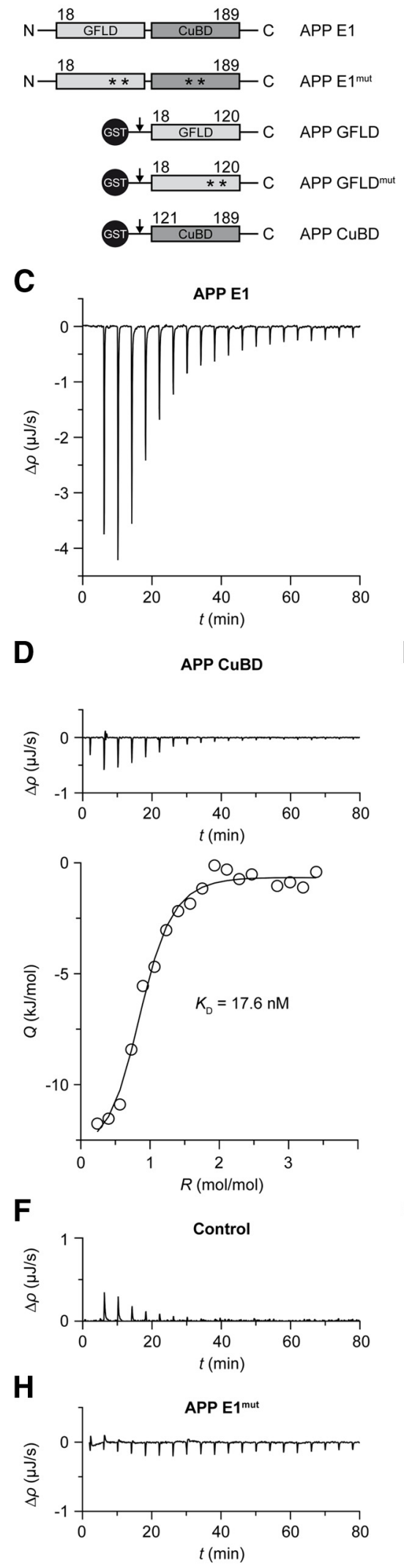

B
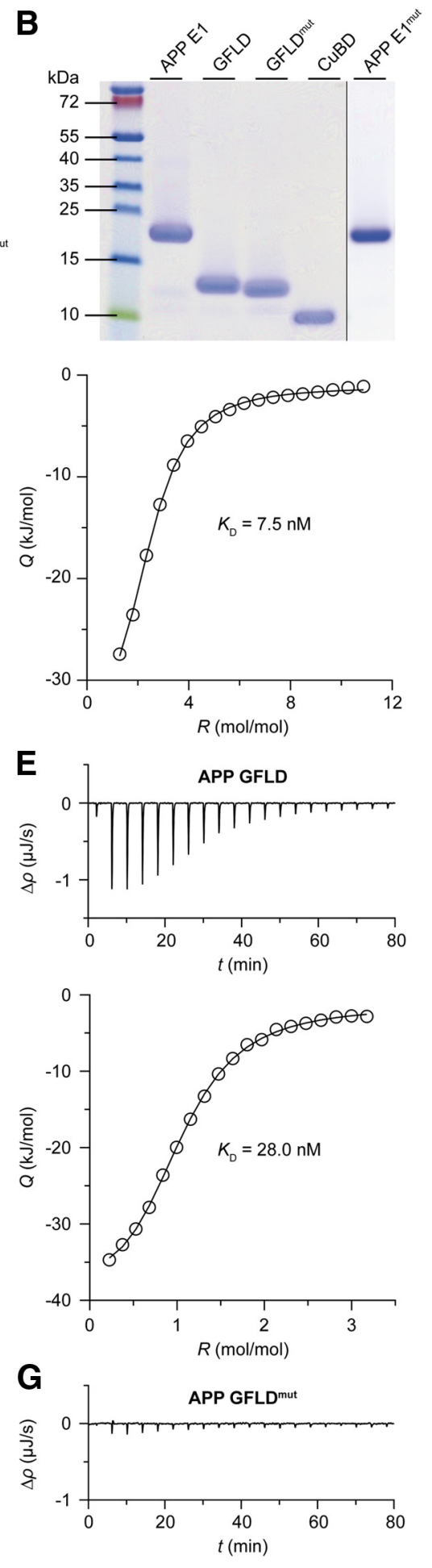

Figure 2. Copper binds to the GFLD of APP. A, Scheme of the APP subdomains used for ITC. The positions of the GFLD (light gray), CuBD (dark gray), and the N-terminal GST epitope (black circle) are indicated. The protease cleavage site is indicated by an arrow, and the sites of mutation are indicated by an asterisk. B, SDS-PAGE of the affinity-purified APP subdomains stained with Coomassie blue. $\boldsymbol{C}-\boldsymbol{H}$, ITC data recorded at $25^{\circ} \mathrm{C}$. Titration of glycine-complexed $\mathrm{CuCl}_{2}$ into $20 \mu \mathrm{m}$ APPE1 (C), $13 \mu \mathrm{m}$ APP CuBD (D), $14 \mu \mathrm{m}$ APP GFLD $(\boldsymbol{E})$, HEPES buffer as control $(\boldsymbol{F}), 38 \mu \mathrm{M}$ APP GFLD H108/110A (GFLD ${ }^{\text {mut }}$ ) $(\boldsymbol{G})$, or $43 \mu \mathrm{M}$ APP E1 H108/110/ al., 2005). In the presence of $250 \mu \mathrm{M}$ copper, we observed a twofold to threefold increase in APP dimer formation $(n \geq 3$; unpaired Student's $t$ test, $p=0.005$; Fig. 3D).

Because it has been previously reported that zinc and iron (II) bind to APP (Bush et al., 1993; Duce et al., 2010), we also tested the influence of these metal ions on APP dimer formation (Fig. $3 E, F$ ). In contrast to copper, we observed no increase in APP dimerization after addition of 50 or $250 \mu \mathrm{M}$ zinc or iron (II) (Fig. 3D). Thus, we conclude that only copper is able to specifically promote APP dimerization.

To validate that the copper-mediated increase in APP dimerization is attributable to the copper-binding sites in the GFLD and CuBD, we generated a set of mutant human myc-tagged $\mathrm{APP}_{695}$ variants lacking either the E1 domain $(\Delta \mathrm{E} 1)$ or the loop region (APP $\Delta 91-111)$ or carrying single amino acid exchanges of the copper-binding histidine residues in the GFLD (GFLD ${ }^{\text {mut }}$ ) or CuBD (CuBD ${ }^{\text {mut }}$; Fig. 4A). Recently, it has been reported that some histidine-to-asparagine substitutions in the $\mathrm{CuBD}$ alter the maturation and subcellular localization of APP (Spoerri et al., 2012). Therefore, we tested whether the introduced mutations might also affect APP subcellular localization, which in turn could interfere with APP dimerization properties. Western blot analysis confirmed the expected MWs of the different APP mutants (Fig. 4B). In immunocytochemical analyses, only mutant APP $\Delta$ 91-111 showed a pronounced ER localization compared with wild-type APP (APP FL), as validated by costaining with the ER marker mRFP-KDEL and Pearson's correlation analysis in HeLa cells $(n=3$; ANOVA with Tukey's HSD post hoc test, $p=0.0002$; Fig. $4 C, D)$. These data indicate that deletion of the loop region causes folding problems that retain APP in the ER. Notably, identical results were also obtained with HEK293 cells (data not shown). Therefore, we excluded APP $\Delta$ 91-111 from additional analyses. All other APP mutants showed no significant changes in their subcellular localization

$\leftarrow$

147/151A (APP E1 ${ }^{\text {mut }}$ ) $(\boldsymbol{H})$. The panels in $\boldsymbol{C}$ (left) and $\boldsymbol{D}$ and $\boldsymbol{E}$ (top) show the differential heating power $(\Delta p)$ versus time $(t)$ plot. C (right), D,E (bottom), Normalized heat of reaction ( $Q$ ) versus molar copper/protein ratio $(R)$. Copper binds with high affinities to the APPE1 domain $\left(K_{D}=7.5 \mathrm{nM}\right)$, the CuBD $\left(K_{\mathrm{D}}=\right.$ $18 \mathrm{nM})$, and the GFLD $\left(K_{D}=28 \mathrm{~nm}\right)$. Binding to the APP GFLD or APP E1 is completely abolished by substitution of the coppercoordinating histidines $\mathrm{H} 108 / \mathrm{H} 110$ or $\mathrm{H} 108 / \mathrm{H} 110 / \mathrm{H} 147 /$ H151 with alanine residues, respectively. 
Table 2. Thermodynamic values from the analysis of the ITC experiments

\begin{tabular}{lllllllllr}
\hline & $n$ & $K_{\mathrm{D}}(\mathrm{nm})$ & $K_{\mathrm{D} 1}(\mu \mathrm{M})$ & $K_{\mathrm{D} 2}(\mu \mathrm{M})$ & $\Delta H^{\circ}(\mathrm{kJ} / \mathrm{mol})$ & $\Delta H_{1}^{\circ}(\mathrm{kJ} / \mathrm{mol})$ & $\Delta H_{2}{ }^{\circ}(\mathrm{kJ} / \mathrm{mol})$ & $\Delta G^{\circ}(\mathrm{kJ} / \mathrm{mol})$ & $-T \Delta S^{\circ}(\mathrm{kJ} / \mathrm{mol})$ \\
\hline $\mathrm{Cu}^{2+}-\mathrm{Gly}_{2}{ }^{a}$ & $*$ & $*$ & 1.6 & 31 & $*$ & -1.5 & -5.7 & $*$ & $*$ \\
$\mathrm{Cu}^{2+}-\mathrm{APPE} 1$ & 3.5 & 7.5 & $*$ & $*$ & -35.8 & $*$ & $*$ & -46.4 \\
$\mathrm{Cu}^{2+}-\mathrm{GFLD}$ & 1.5 & 28.0 & $*$ & $*$ & -40.0 & $*$ & $*$ & -43.1 & 3.1 \\
$\mathrm{Cu}^{2+}-\mathrm{CuBD}$ & 1.1 & 17.6 & $*$ & $*$ & -18.0 & $*$ & $*$ & -44.3 & 26.2 \\
\hline
\end{tabular}

*Not applicable.

${ }^{a}$ Martell et al. (2004).

A

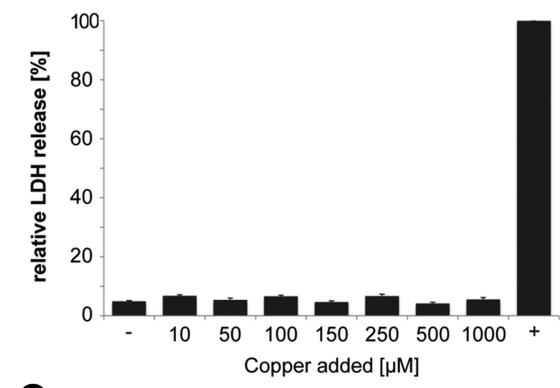

c

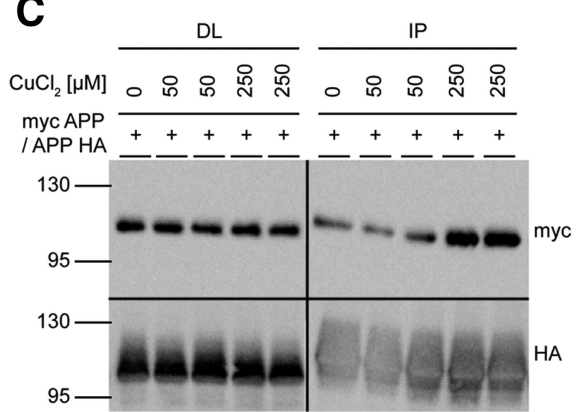

B

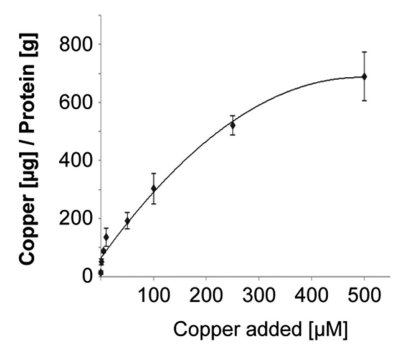

D

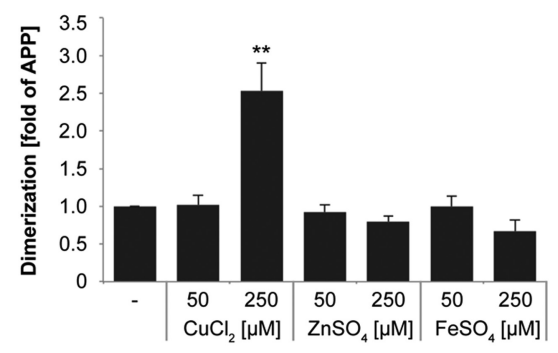

E

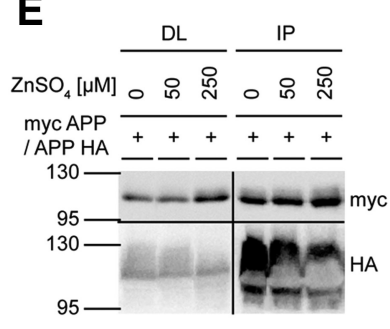

$\mathbf{F}$

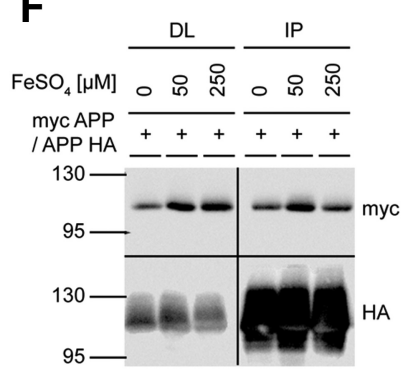

Figure 3. Copper promotes APP dimerization. $A$, Analysis of cell viability monitored by LDH release. HEK293 cells were incubated for $4 \mathrm{~h}$ in growth medium supplemented with the indicated amounts of copper, and LDH released into the medium was measured. Maximal LDH released into the medium was determined after cell lysis with Triton X-100 $(+)(n=3)$. B, Cellular copper uptake monitored by ICP-0ES. HEK293 cells were incubated for $4 \mathrm{~h}$ in growth medium supplemented with the indicated amounts of copper, and the cellular copper concentration normalized to protein levels was determined $(n=3)$. C, Co-IP analysis of HA- and myc-tagged APP with increasing copper concentrations. HEK293 cells were transiently cotransfected with C-terminal HA-tagged (APP HA) and N-terminal myc-tagged (myc APP) APP and incubated with the indicated amounts of glycine-complexed $\mathrm{CuCl}_{2}$ for 4h. Anti-HA immunoprecipitates from cell extracts (IP) were immunoblotted for HA- and myc-tagged proteins (DL, direct load). $\boldsymbol{D}$, Quantification of $\mathrm{Co}-\mathrm{IP}$ analysis revealed significantly increased dimerization in the presence of $250 \mu \mathrm{m}$ copper. Mean protein levels were normalized to APP \pm SEM $\left(n \geq 3\right.$; unpaired Student's $t$ test, $\left.{ }^{* *} p<0.01\right) . E, F$, Co-IP analyses of HA- and myc-tagged APP with increasing concentrations of zinc (E) and iron (II) (F).

compared with wild-type APP and were used to test for APP dimerization properties in Co-IP experiments.

As observed previously (Soba et al., 2005), APP lacking the entire E1 domain $(\Delta \mathrm{E} 1)$ displayed very poor interaction with APP FL ( $n \geq 4$; unpaired Student's $t$ test, $p=0.0002)$. APP lacking either the GFLD $(\Delta \mathrm{GFLD}, p=0.02)$ or the CuBD $(\Delta \mathrm{CuBD}, p=0.02$ ) also showed impaired dimerization (Fig. $5 A, B, E)$. Similarly, alanine substitutions of the ligating histidine res- idues in either the GFLD (H108, H110; $\left.\mathrm{GFLD}^{\mathrm{mut}}, p=0.001\right)$ or the CuBD (H147, $\mathrm{H} 151$; $\left.\mathrm{CuBD}^{\text {mut }}, p=0.038\right)$ or both $\left(\mathrm{C} / \mathrm{G}^{\mathrm{mut}}, p=0.012\right)$ revealed impairments in dimerization, whereas control mutants (H137A, $p=0.18$ and E183A, $p=0.42$ ) had no effects when coimmunoprecipitated with wild-type APP (Fig. 5A,C). Quantification of Co-IP data revealed that the dimerization of copper bindingdeficient APP was impaired by $10-20 \%$, whereas deletion of the entire subdomains almost abolished dimerization with APP FL (Fig. $5 B, C, E$ ).

In a next step, we aimed to test whether mutations of copper-binding sites in both of the interacting APP molecules have an additive effect on dimerization compared with dimers composed of one wild-type and one copper binding-deficient APP. For this purpose, we precipitated different myc-tagged APP mutants with HA-tagged mutant APP (H108/110A; GFLD ${ }^{\text {mut }}$ HA) instead of HA-tagged wild-type APP. Remarkably, Co-IP of APP GFLD ${ }^{\text {mut }}$, $\mathrm{CuBD}^{\text {mut }}$, or $\mathrm{C} / \mathrm{G}^{\text {mut }}$ with APP mutated in the GFLD (GFLD ${ }^{\text {mut }} \mathrm{HA}$ ) was impaired more strongly $(30-60 \%)$ than Co-IP with wild-type APP (10-20\%; $n \geq$ 4; unpaired Student's $t$ test, $p=0.004$ for GFLD $^{\text {mut }}, p=0.013$ for $\mathrm{CuBD}^{\text {mut }}, p=$ 0.008 for $\mathrm{C} / \mathrm{G}^{\text {mut }}$; Fig. $5 D, E$ ), suggesting that copper binding to both the CuBD and the GFLD is required for APP dimerization.

Together, these observations provide clear evidence that elevated copper levels promote APP dimerization by binding to the CuBD and GFLD, by either directly participating in the intermolecular interaction or favoring a conformational change within the E1 domain.

\section{Copper promotes APP trans- dimerization in a heparin- independent manner}

Based on the results showing copper-dependent APP cisdimerization, we assumed that copper may also affect APP dimerization in a trans-directed manner. For this purpose, we used a cell-free standard bead aggregation assay as applied for the analysis of different cell and synaptic adhesion proteins, such as Cadherins or SynCAM (Lambert et al., 2000; Chappuis-Flament et al., 2001; Galuska et al., 2010; Chavda et al., 2013). We purified 
A

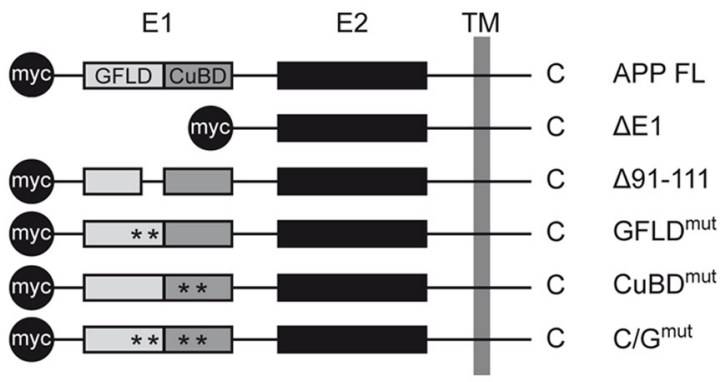

B

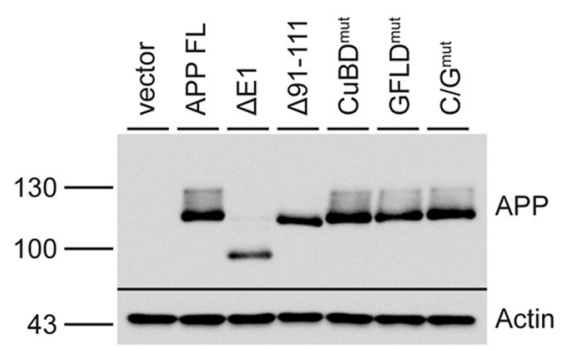

C
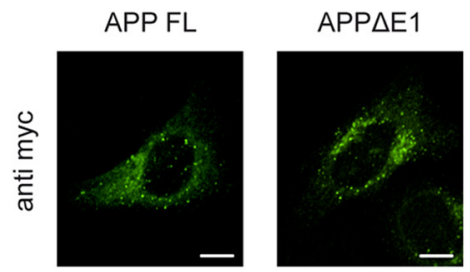

APP $\triangle 91-111$
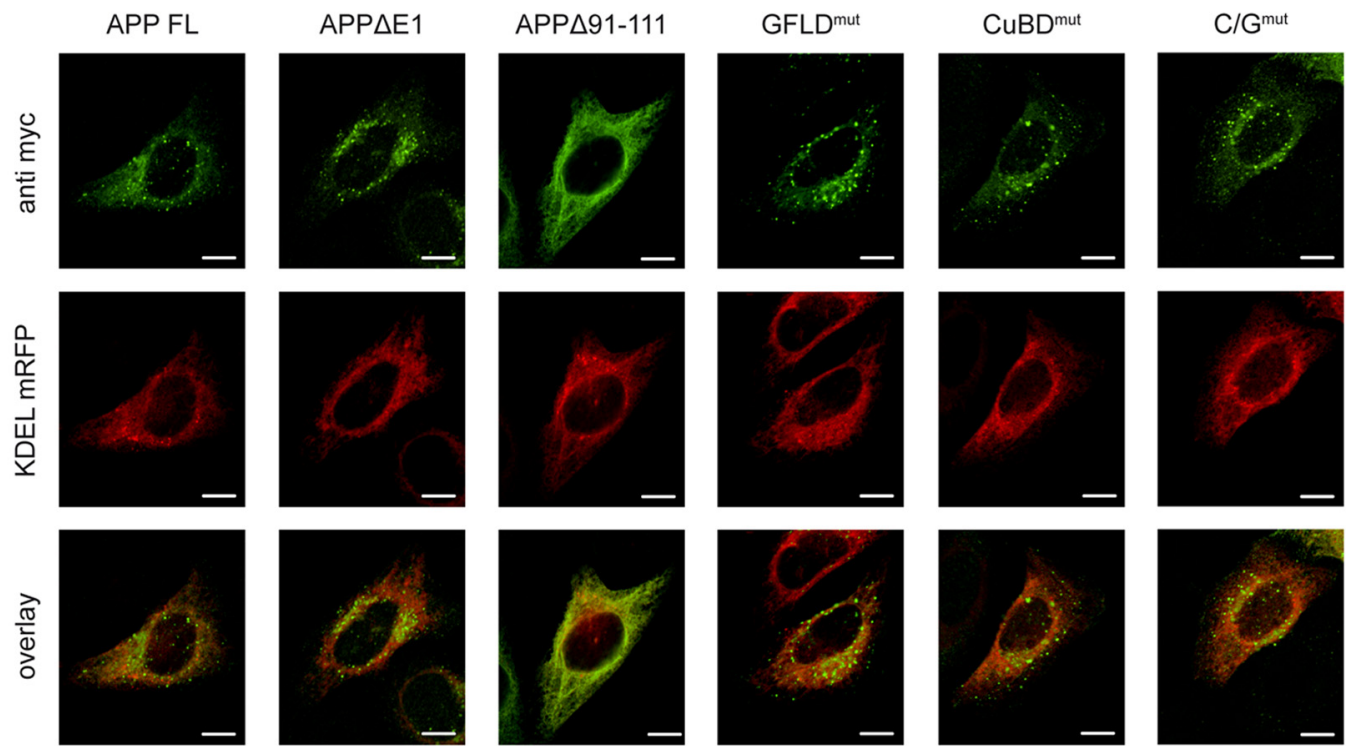

D

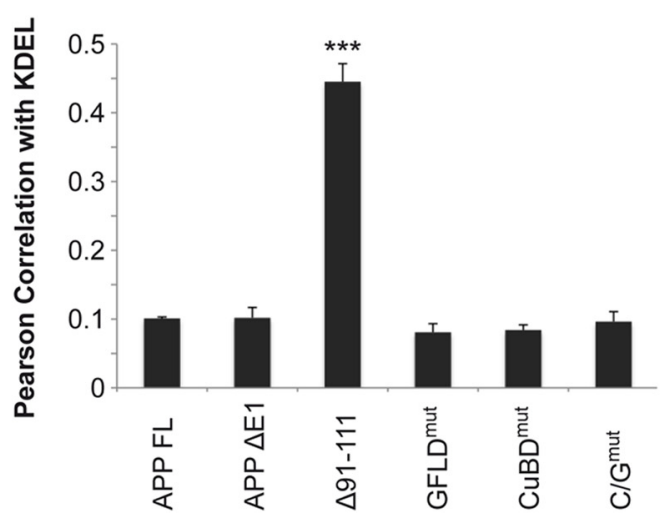

Figure 4. Mutations of copper-binding sites do not affect cellular trafficking of APP. A, Scheme of APP constructs used. $\triangle$ E1, APP lacking the E1 domain; $\triangle 91-111, A P P$ lacking the LBL; GFLD mut, APP H108/110A; CuBD ${ }^{\text {mut }}$, APP H147/151A; C/G ${ }^{\text {mut }}$, APP H108/110A and H147/151A; E1, E1 domain (gray); E2, E2 domain (black); TM, transmembrane domain; *, site of mutation; myc, N-terminal fused c-myc epitope. The positions of the GFLD (light gray) and CuBD (dark gray) are indicated. $\boldsymbol{B}$, Western blot analysis of APP constructs expressed in HeLa cells. APP proteins were detected by W0-2 antibody and actin by AC-15 antibody. C, Fluorescence micrographs of HeLa cells expressing the different myc-tagged APP constructs (green). Heterologously expressed APP was visualized by an anti-myc antibody and the ER by coexpression of mRFP-tagged KDEL fusion protein (red). $\boldsymbol{D}$, Pearson's correlation coefficient of APP with mRFP-KDEL. Bars represent mean \pm SEM values of three independent experiments (ANOVA with Tukey's HSD post hoc test, ${ }^{* *} p<0.01$ ).

the extracellular domain of APP fused to the $\mathrm{F}_{\mathrm{C}}$ domain of a human IgG1 (APPex- $\mathrm{F}_{\text {; }}$; Baumgartner et al., 2000; Lambert et al., 2000) by protein A affinity chromatography (Fig. 6A,B). Copper-dependent adhesive properties of APP were tested by incubation of APPex- $\mathrm{F}_{\mathrm{C}}$-coated beads in HEPES buffer at increasing concentrations of copper (1-100 $\mu \mathrm{M})$. After $2 \mathrm{~h}$, samples were subjected to microscopic analysis (Fig. $6 \mathrm{C}$ ) and quantitatively analyzed by counting aggregates $>10 \mu \mathrm{m}$ in a Coulter 
A

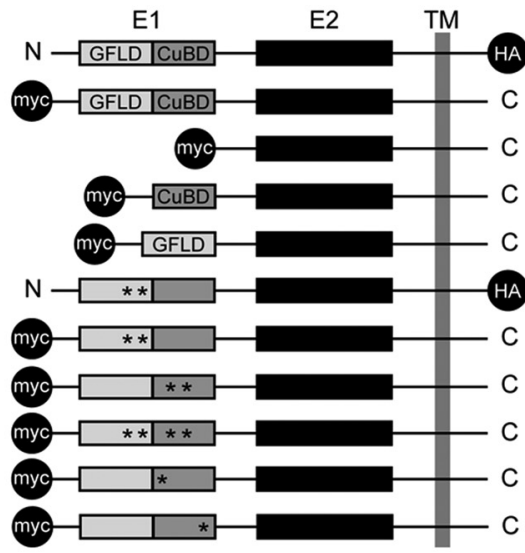

APP HA

myc APP

$\triangle E 1$

$\triangle G F L D$

$\triangle$ CUBD

GFLD ${ }^{\text {mut }} H A$

GFLD ${ }^{\text {mut }}$

CuBD mut

$\mathrm{C} / \mathrm{G}^{\mathrm{mut}}$

H137A

E183A
B

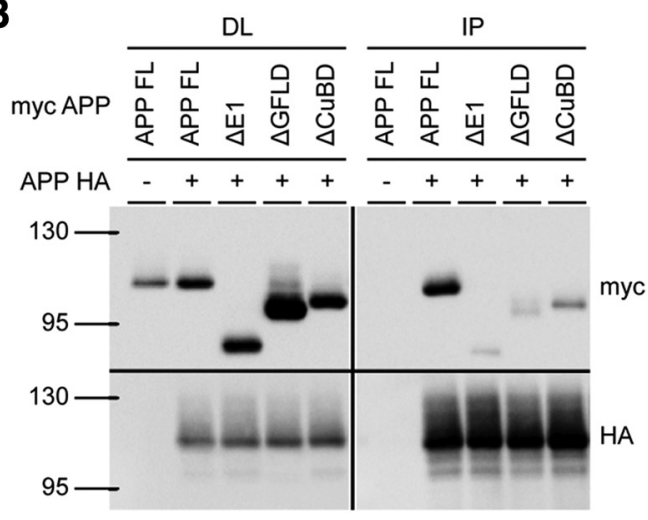

C

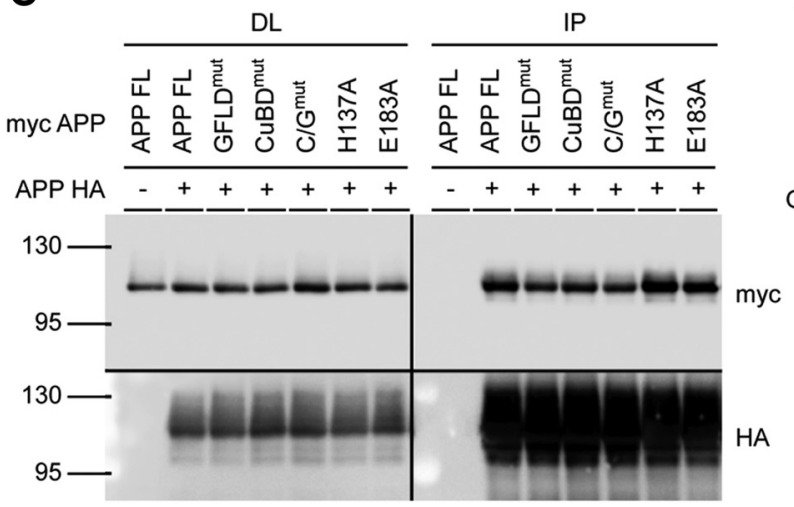

D

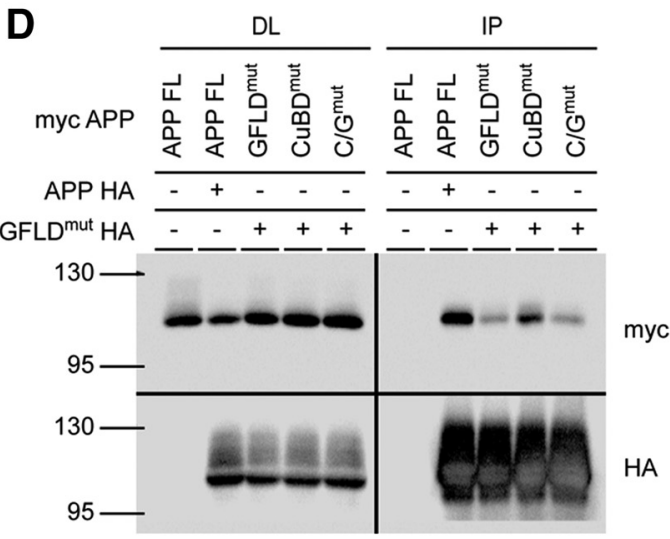

E

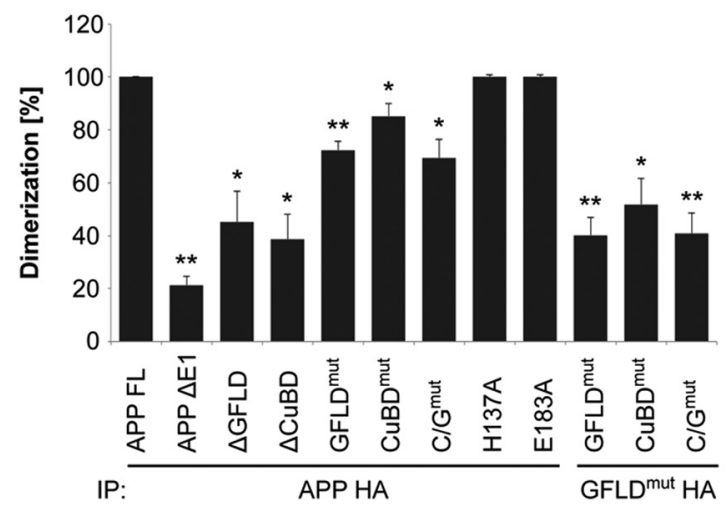

Figure 5. Intracellular APP dimerization depends on copper binding. Co-IP analysis of HA- and myc-tagged APP in HEK293 cells. A, Scheme of APP constructs used (as described in Fig. 4). APP HA, HA-tagged full-length APP; APP FL, myc-tagged full-length APP; $\triangle$ GFLD, APP lacking the GFLD; $\triangle$ CuBD, APP lacking the CuBD; HA, C-terminal fused HA epitope; myc, N-terminal fused c-myc epitope. The positions of the GFLD (light gray) and CuBD (dark gray) are indicated. HA-tagged full-length APP (APP HA) was transiently coexpressed with APP FL, $\triangle E 1, \triangle G F L D$, or $\triangle$ CuBD (B) and APP FL, GFLD ${ }^{\text {mut }}$, CuBD ${ }^{\text {mut }}$, C/G ${ }^{\text {mut }}$, APP H137A, or APP H183A (C). D, Mutated HA-tagged APP (GFLD ${ }^{\text {mut }}$ HA) was transiently coexpressed with APP FL, GFLD ${ }^{\text {mut }}$, CuBD ${ }^{\text {mut }}$, or C/G ${ }^{\text {mut }}$. Anti-HA immunoprecipitates from cell extracts (IP) were immunoblotted for HA- and myc-tagged proteins. DL, direct load. E, Quantification of Co-IP analysis revealed significant changes between APP FL and all APP constructs with mutations/deletions of the copper-binding sites. Mean protein levels were normalized to APP FL \pm SEM ( $n \geq 4$; unpaired Student's $t$ test, ${ }^{*} p<0.05$, $\left.{ }^{* *} p<0.01\right)$.

Counter Z2 particle counter (Fig. 6D). Aggregation was observed only for beads coated with APPex- $\mathrm{F}_{\mathrm{C}}$ but not for $\mathrm{F}_{\mathrm{C}}$-coated control beads, demonstrating for the first time a direct homophilic trans-directed interaction of APP in a cell-free assay. Furthermore, bead aggregation only took place in the presence of low copper concentrations ( $5 \mu \mathrm{M} ; n \geq 3$; unpaired Student's $t$ test, $p=0.005)$, suggesting a pivotal role of copper in APP transdimerization. Increasing the concentration of copper from 5 to $100 \mu \mathrm{M}$ elicited only a small increase in the number of aggregates
( $n \geq 3$; unpaired Student's $t$ test, $p=0.021$ for $10 \mu \mathrm{M}, p=0.005$ for $50 \mu \mathrm{M}$, and $p=0.002$ for $100 \mu \mathrm{M}$ copper), indicating a saturation of copper-mediated APP trans-dimerization. Moreover, treatment with EDTA $(1 \mathrm{~mm})$ fully reversed bead aggregation ( $n=3$; unpaired Student's $t$ test, $p=0.003$ ), demonstrating that copper-mediated bead clustering is not caused by unspecific protein aggregation.

Besides copper, we tested also the influence of zinc and iron (II) on APP trans-dimerization (Fig. 6D). Treatment with iron 
A

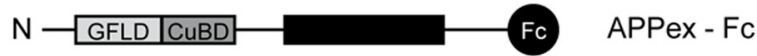

B

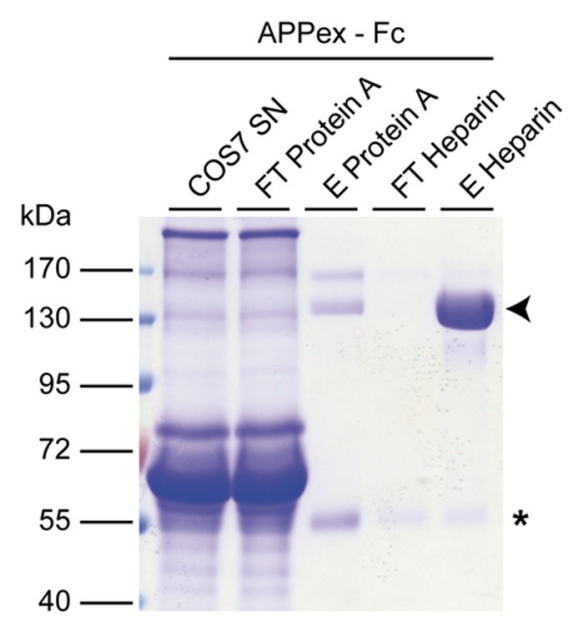

C

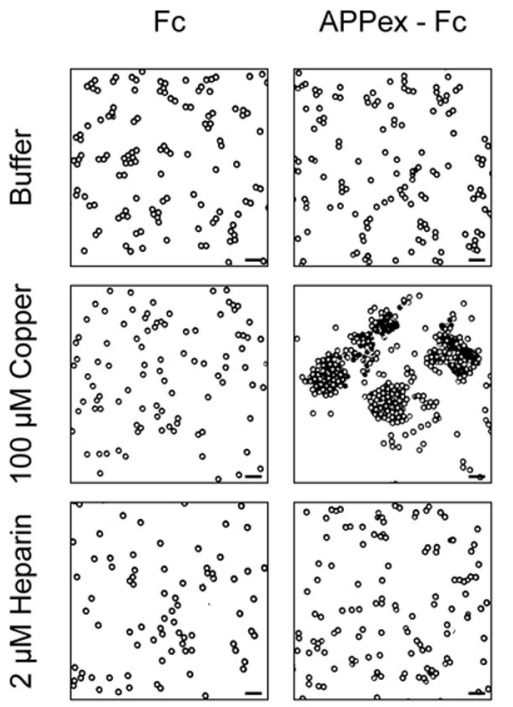

D

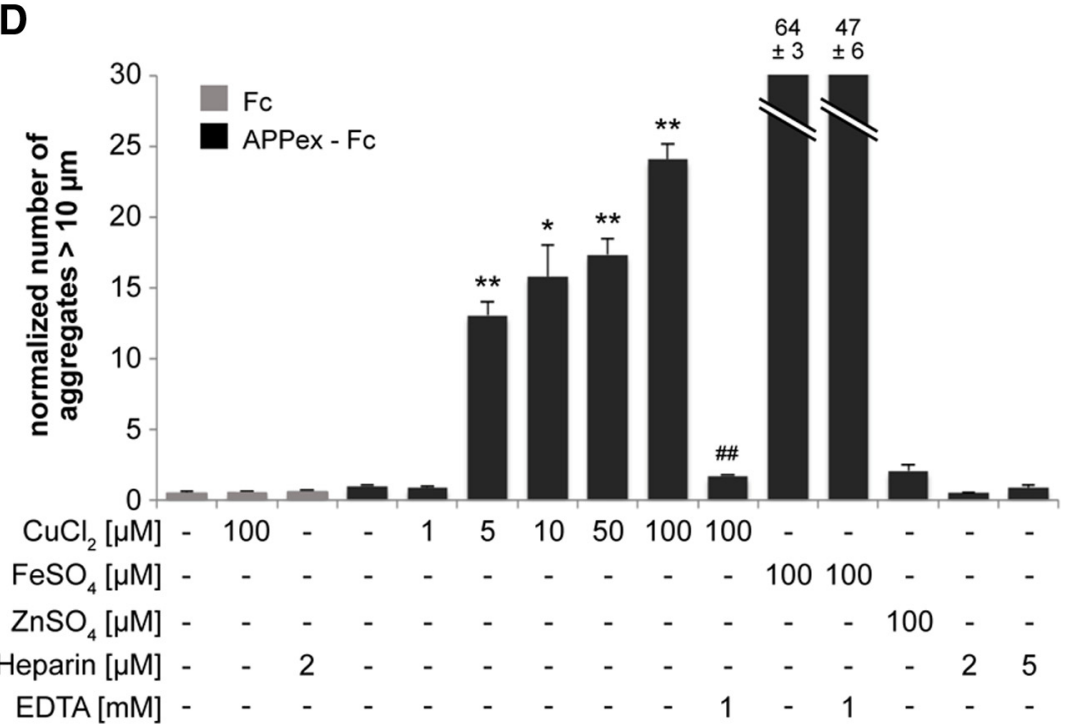

E

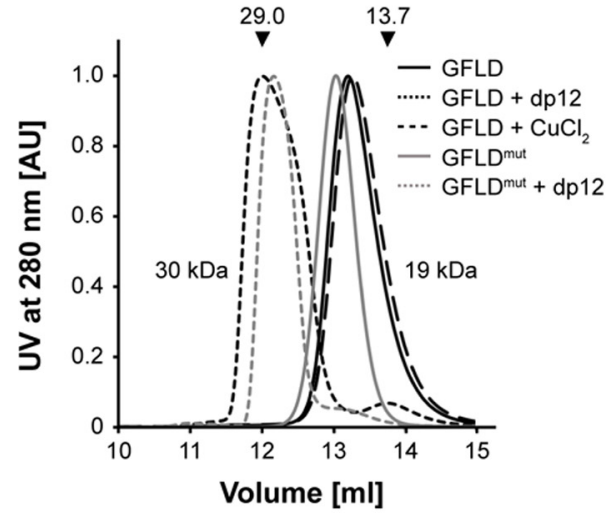

Figure 6. Copper promotes APP trans-dimerization. $\boldsymbol{A}$, Scheme of APPex fused to the $\mathrm{F}_{\mathrm{C}}$ domain of human lgG1 ( $\mathrm{F}_{\mathrm{C}}$ ) (APPex- $\mathrm{F}_{\mathrm{C}}$ ). $\boldsymbol{B}$, Coomassie blue-stained SDS-PAGE of the APPex- $\mathrm{F}_{\mathrm{C}}$ (arrowhead) purification from conditioned medium of $\operatorname{COS7}$ cells (COS7 SN) stably expressing APPex- $\mathrm{F}_{\mathrm{C}}$ by protein A and heparin affinity chromatography. $\mathrm{FT}$, Flow through; $\mathrm{E}$, eluate; ${ }^{*}$, MW of IgG heavy chain. C, Representative micrographs of clustered protein A beads coated with either $\mathrm{F}_{\mathrm{C}}$ or APPex- $\mathrm{F}_{\mathrm{C}}$ in the presence or absence of $100 \mu \mathrm{m}$ copper or $2 \mu \mathrm{m}$ heparin dodecasaccharide (dp12). Scale bar, 10 $\mu \mathrm{m} . \boldsymbol{D}$, Quantification of clustered protein A beads incubated with the indicated amounts of copper, iron, or zinc, as well as Heparin dp12 or EDTA. Aggregates $>10 \mu \mathrm{m}$ were measured with a Coulter Counter Z2 particle counter. Aperture tube, $100 \mu \mathrm{m}$. Bars represent mean \pm SEM values of at least three independent experiments (unpaired Student's $t$ test, ${ }^{*} p<0.05$ and ${ }^{* *} p<0.01$

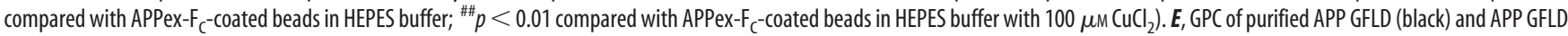
$\mathrm{H108/110A} \mathrm{(GFLD}{ }^{\text {mut; }}$ gray) in the absence (solid line) or presence of either 10-fold molar excess of heparin dodecasaccharide (dp12; dashed line) or 50-fold molar excess of $\mathrm{CuCl}_{2}$ (broken line). The median apparent MWs and the elution volumes of the marker proteins carbonic anhydrase $\left(M_{\mathrm{r}}=29,000\right)$ and ribonuclease $A\left(M_{\mathrm{r}}=13,700\right)$ are indicated $(\boldsymbol{\nabla})$.

(II) $(100 \mu \mathrm{M})$ caused a drastic increase in the number of aggregates that was not fully reversed by the addition of EDTA (1 mM), indicating an unspecific protein aggregation. The addition of zinc $(100 \mu \mathrm{M})$ did not elicit a significant increase in bead aggregation, demonstrating that only copper is able to reversibly increase trans-dimerization of the APP ectodomain.

Heparin has been reported to induce dimerization of sAPP or the APP E1 domain as shown previously by GPC (Gralle et al., 2006; Dahms et al., 2010). Therefore, we tested whether addition of heparin might also promote bead clustering and whether copper might affect this interaction. For this purpose, we incubated APPex- $\mathrm{F}_{\mathrm{C}}$-coupled beads with a 10 -fold and 25 fold molar excess ( 2 and $5 \mu \mathrm{M}$, respectively) of LMW heparin (heparin dodecasaccharide; dp12). Surprisingly, we observed no trans-dimerization-promoting activity for heparin (Fig. $6 D)$, suggesting that copper and heparin promote APP dimerization in different ways. In line with this assumption, we observed in GPC analyses that the purified GFLD dimerized after addition of a 10-fold molar excess of heparin (Fig. 6E), whereas neither addition of copper in 50-fold molar excess nor alanine substitutions of the copper ligating histidine residues in the GFLD ( $\mathrm{H} 108$ and $\mathrm{H} 110)$ affected the 
A
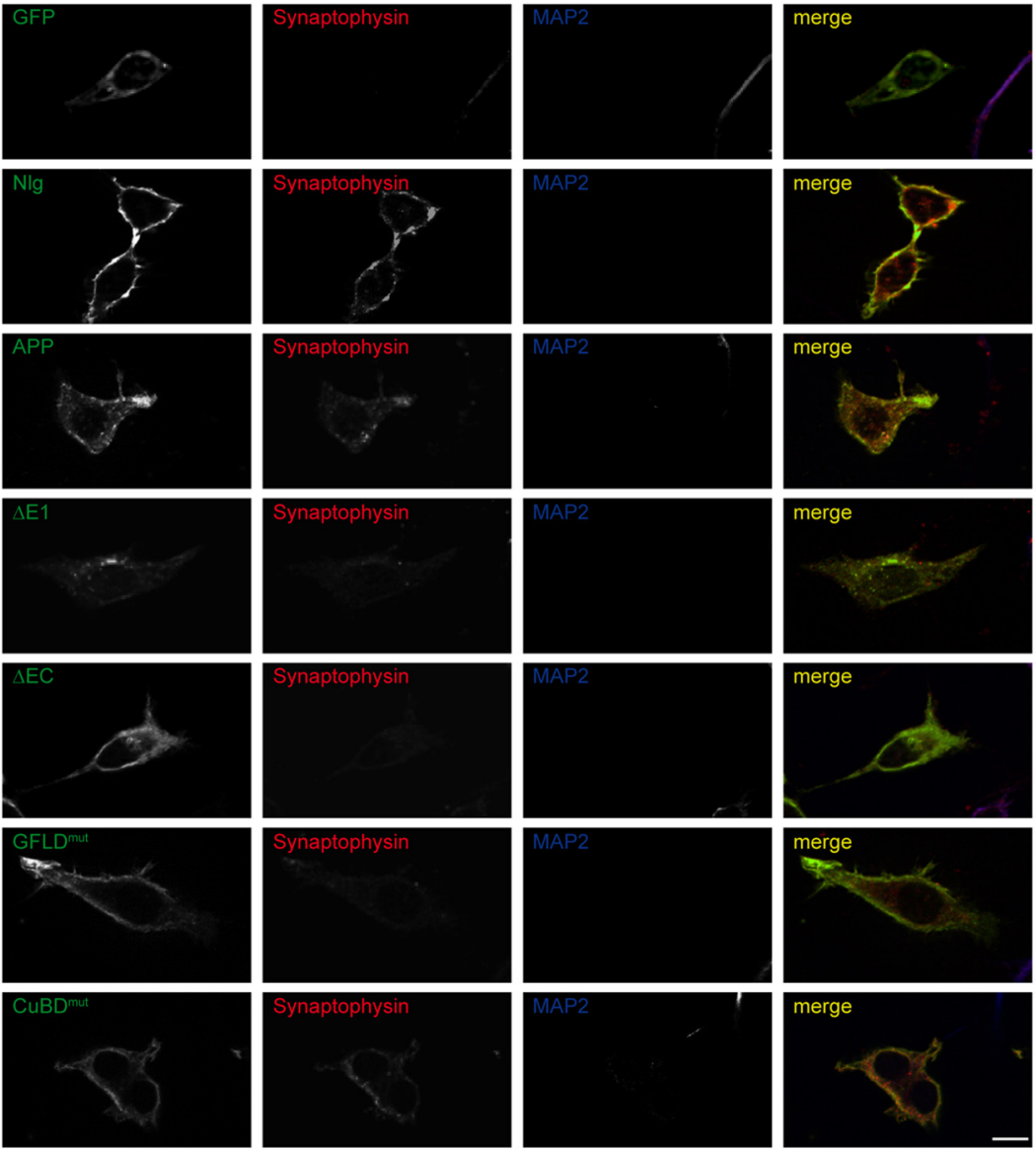

B
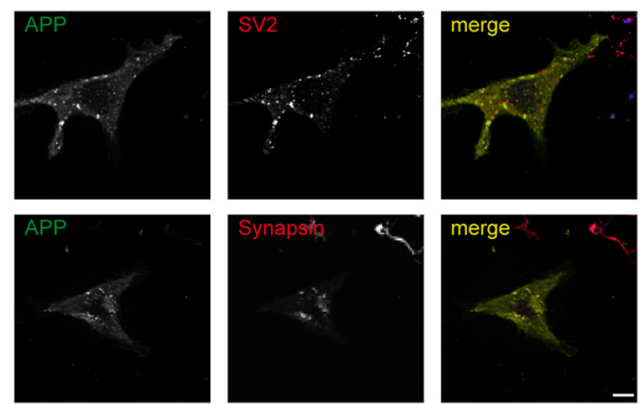

D
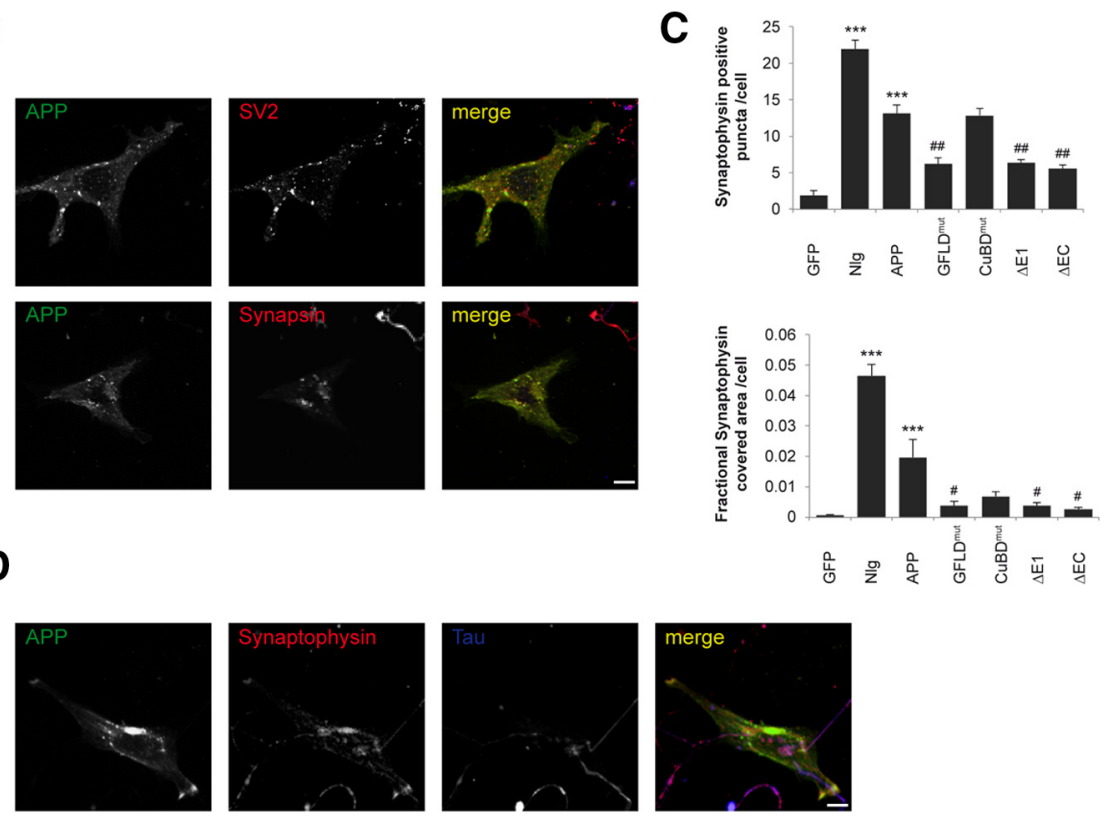

Figure 7. Mutation of APP copper-binding sites decreases APP synaptogenic activity. Hemisynapse analysis of APP synaptogenic activity. $\boldsymbol{A}$, Representative micrographs of immunostainings of HEK293 cells expressing either GFP, Neuroligin-1 (NIg), APP $\mathrm{FL}$, APP lacking the E1 domain ( $\Delta \mathrm{E} 1)$, APP lacking the entire extracellular domain ( $\triangle \mathrm{EC})$, APP H108/110A (GFLD ${ }^{\text {mut }}$ ), or APP H147/151A (CuBD ${ }^{\text {mut }}$ ), cocultured with primary cortical neurons. Cells were stained with anti-Synaptophysin (red) and anti-MAP2 (blue) antibodies. Synaptophysin-positive but MAP2-negative puncta are visible on top of Nlg- and APP-transfected cells (green). Scale bar, $10 \mu \mathrm{m}$. B, Immunostaining of APP-expressing HEK293 cells cocultured with primary cortical neurons. Cells were stained with anti-SV2 (red) and anti-Synapsin-1 (red) antibodies to demonstrate the recruitment of presynaptic marker proteins. Scale bar, $10 \mu \mathrm{m}$. C, Quantification of Synaptophysin-positive puncta per transfected HEK293 cell and Synaptophysin-covered area per HEK293 cell (5-7 cells per experiment). Bars representmean \pm SEM values of at least three independent experiments (ANOVA with Tukey's heparin-induced dimerization (Fig. $6 E)$. Notably, the mobility shift caused by addition of heparin show minor differences between the GFLD and the GFLD $^{\text {mut }}$, which might be attributable to subtle alterations in heparin binding.

Together, our data from the bead aggregation assay and the GPC corroborate the assumption that heparin- and copperinduced dimerization processes are independent from each other and thus are likely underlying different molecular mechanisms.

\section{APP synaptogenic function depends on copper binding}

The above studies provide substantial evidence that copper promotes transdirected APP interaction. In previous studies using a mixed-culture system (Scheiffele et al., 2000; Graf et al., 2004; Biederer and Scheiffele, 2007), it has been shown that expression of APP in HEK293 cells causes a recruitment of contacting axons from cocultured primary neurons (Wang et al., 2009). To investigate the synaptogenic properties of APP in dependence of copper, we transiently transfected Neuroligin-1 (Nlg), wild-type APP (APP FL), APP lacking the entire extracellular domain (APP $\triangle E C$ ), APP lacking the E1 domain (APP $\triangle E 1)$, and the copperbinding-deficient APP mutants (APP GFLD $^{\text {mut }}$ and $\mathrm{CuBD}^{\text {mut }}$ ), as well as GFP expression constructs in HEK293 cells. The transfected cells were cocultured with dissociated cortical neurons. Transfection with Nlg cDNA was performed as a positive control (Scheiffele et al., 2000), whereas heterologous expression of GFP alone was used as a negative control (Fig. 7A). Similar to Nlg, expression of APP but not GFP in HEK293 cells potently promoted synaptic puncta formation as measured by both the number of synaptic puncta per transfected HEK293 cell and the area of HEK293 cells covered by Synaptophysin (Fig. 7C). Most importantly, concentrations of synaptic vesicles were found at contact sites between APPexpressing HEK293 cells and Tau-positive axons of cocultured neurons, as indicated by Synaptophysin, SV2, and Synapsin-1 immunoreactivity (Fig. $7 A, B, D)$. These

$\leftarrow$

HSD post hoc test, ${ }^{*} p<0.05$, ${ }^{* *} p<0.01$, and ${ }^{* * *} p<0.001$ compared with GFP; $p<0.05$ and ${ }^{\# \#} p<0.01$ compared with APP FL). D, APP-expressing HEK293 cells cocultured with primary cortical neurons were stained with anti-Synaptophysin (red) and anti-Tau1 (blue) antibodies to visualize an accumulation of Synaptophysin at contact sites between the axon and HEK293 cells. Scale bar, $10 \mu \mathrm{m}$. 
data are consistent with the results of Wang et al. (2009). We found that APP lacking the entire extracellular domain or the E1 domain or carrying mutations at the copper-binding site in the GFLD (GFLD $^{\text {mut }}$ ) showed an $\sim 50 \%$ lowered amount of Synaptophysin puncta and a reduced cell area covered by Synaptophysin on the transfected HEK293 cells (Fig. 7A,C). Remarkably, replacement of the copper coordinating histidine residues in the $\mathrm{CuBD}\left(\mathrm{CuBD}^{\text {mut }}\right)$ did not significantly reduce the amount of Synaptophysin-positive puncta compared with APP (Fig. 7 A, C). Additionally, the area covered by Synaptophysin, although smaller, was not significantly changed. Together, these data corroborate our hypothesis that APP synaptogenic activity mainly depends on copper binding to the GFLD.

\section{Discussion}

Here, we show that copper binding to both the CuBD and the newly identified binding site in the GFLD promotes APP dimerization in both a cis- and transcellular manner, affecting APP physiological function at the synapse. Specific and high-affinity binding of copper to $\mathrm{H} 108$ / $\mathrm{H} 110$ in the GFLD is validated by a crystal structure of the GFLD in complex with copper and by ITC measurements. Interestingly, the binding affinity for the GFLD is very similar to that for the CuBD (Hesse et al., 1994). Although binding might occur independently to each of the two domains, a common binding of one copper ion could be envisaged as the copper ligation geometries of the GFLD (Fig. 1) and the CuBD (Kong et al., 2007a) perfectly complement each other by replacing the ligating symmetry or water molecules with the respective coordinating residues. Sequence alignment of the copper-binding site in the GFLD shows that the copperbinding histidines of APP are conserved in mammals and also in APLP1 but not in APLP2 (Fig. 1). In contrast, the copper-binding residues in the CuBD are conserved in APP and APLP2 but not in APLP1 (Kong et al., 2008). Thus, common binding of one copper ion by the GFLD and the CuBD might be a unique feature of APP.

In contrast with copper binding to the CuBD (Kong et al., 2007b, 2008), comparison of the crystals of the GFLD • Cu crystal structure with the apo structure (Rossjohn et al., 1999; Dahms et al., 2010) reveals clear structural changes involving disulfide reduction in the LBL. This might contribute to the previously described redox activity of APP (Multhaup et al., 1996). Interestingly, these alterations are observed in the loop region (LBL), which forms the assumed APP dimerization interface (Kaden et al., 2008; Dahms et al., 2010). Thus, copper binding to the GFLD might provoke a conformational change in the LBL favoring APP dimerization.

Consistently, exposure to increasing copper concentrations (up to $250 \mu \mathrm{M}$ ) causes an elevated APP dimerization in a cis-and trans-directed manner (Fig. 3). In Co-IP studies, we observed that single-point mutations of the copper-binding histidines in the GFLD or CuBD had a similarly strong influence on APP
B

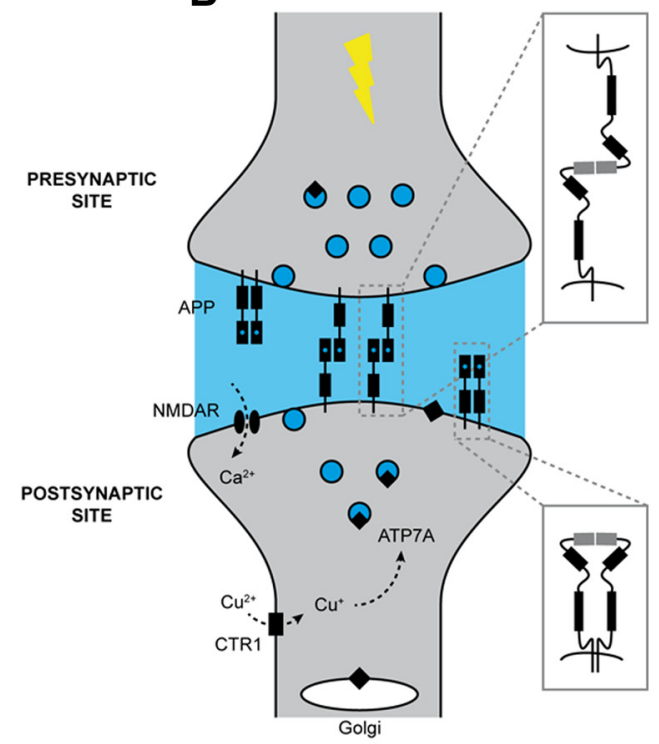

copper bioavailability

Figure 8. Model for copper-induced APP dimerization at the synapse. $\boldsymbol{A}$, Under resting conditions, the copper transporter ATP7A is predominantly localized at the Golgi apparatus, and the copper concentration within the synaptic cleft is low (light blue). Under these conditions, APP present at presynaptic and postsynaptic sites is mainly monomeric. $\boldsymbol{B}$, NMDA receptor activation (he dimerization. CTR1, Copper transporter 1; NMDAR, NMDA receptor; PM, plasma membrane.

dimerization, as had complete deletions of the respective domains (Fig. 5). Together with our results from the bead aggregation assay showing that copper is essential and sufficient to direct APP dimerization (Fig. 6), this strongly suggests a central role of copper in the regulation of APP cis- and trans-directed dimerization (Fig. 8). Notably, in previous S2 cell clustering experiments, we used a copper-induced expression system, in which expression of the target proteins was induced by $500 \mu \mathrm{M}$ copper (Soba et al., 2005). Thus, we most likely observed unintended copperpromoted cell clustering at that time. Although the precise molecular mechanism remains enigmatic, the present data indicate that the CuBD and GFLD are both directly involved in coppermediated dimerization of two interacting APP molecules. In contrast to this, heparin-induced APP dimerization seems to depend solely on the GFLD, as evidenced by GPC analysis with the isolated subdomain (Fig. 6). These observations led to the conclusion that the heparin- and copper-induced dimerization is attributable to noncompetitive independent molecular mechanisms, which is further supported by the fact that alanine substitutions of the copper-binding histidine residues did not affect heparin-induced dimerization in GPC.

Under in vitro conditions, low micromolar concentrations of copper were sufficient to induce APP dimerization, whereas APP dimerization in the cellular context was achieved only at copper concentrations of $\sim 100 \mu \mathrm{M}$. This difference is most likely explained by the complex regulation of copper homeostasis in vivo, because copper taken up by cells is first bound to high-affinity copper-binding components (Banci et al., 2010; Lutsenko et al., 
2010) and thus only available to APP at high intracellular copper levels, when the pool of other high-affinity binding components is saturated. Under physiological conditions, the copper concentration in the human brain is $\sim 80 \mu \mathrm{M}$, with the highest concentration in the hippocampus (Lutsenko et al., 2010; Roberts et al., 2012; Gaier et al., 2013). Higher concentrations are most likely achieved only for short time periods in locally restricted areas, e.g., during synaptic transmission, in which the temporal increase of copper at the synaptic cleft has been reported to reach levels that are even above $250 \mu \mathrm{M}$ (Kardos et al., 1989; Lutsenko et al., 2010; Gaier et al., 2013). These data support the idea that copper might be a regulator of APP trans-dimerization at the synapse (Fig. 8).

In our studies, we further confirmed that expression of APP in HEK293 cells promotes synaptogenesis in contacting axons of cocultured primary neurons (Fig. 7; Wang et al., 2009), similar to the synaptogenic activity of Nlg (Scheiffele et al., 2000). Together with recent data showing synaptic deficits in conditional APP knock-out mice and different APP knock-in mutants (Müller and Zheng, 2012), APP was classified in the group of synaptic cell adhesion molecules (Siddiqui and Craig, 2011). Interestingly, APP carrying mutations at the copper-binding sites in the GFLD showed a dramatic reduction in promoting presynaptic specialization, very similar to the deletion of the APP extracellular domain or the E1 domain. This demonstrates that copper binding to APP is not only essential for trans-dimerization but also required for APP-promoted presynaptic specialization in mixed coculture assays.

Moreover, accumulating evidence suggests important roles for endogenous copper in synaptic function or plasticity, such as a synaptic activity-dependent increase of copper levels at the synaptic cleft (Tamano and Takeda, 2011; Gaier et al., 2013). However, because of the complex interconnected influences exerted by copper ions, additional in vivo studies will be required to decipher the different copper activities at the synapse, including the modulation of the postulated synaptogenic function of APP and prion protein, as well as $\mathrm{GABA}_{\mathrm{A}}$ receptors, NMDA receptors, and voltage-gated calcium channels contributing to synaptic transmission (Gaier et al., 2013).

Although the current data suggest a correlation of APP dimerization, copper binding, and APP processing (Bayer et al., 2006; Kong et al., 2008; Eggert et al., 2009; Sato et al., 2009; Kaden et al., 2012; Spoerri et al., 2012; Noda et al., 2013), the inconsistency of results obtained with these different assay systems does not allow drawing a clear picture yet.

Together, our data provide strong evidence that altered copper homeostasis and/or synaptic activity-dependent changes in extracellular copper levels modulate APP cis- and trans-cellular dimerization, which in turn regulates the physiological function of APP and has a severe affect on its pathogenicity in AD.

\section{References}

Adams PD, Afonine PV, Bunkóczi G, Chen VB, Davis IW, Echols N, Headd JJ, Hung LW, Kapral GJ, Grosse-Kunstleve RW, McCoy AJ, Moriarty NW, Oeffner R, Read RJ, Richardson DC, Richardson JS, Terwilliger TC, Zwart PH (2010) PHENIX: a comprehensive Python-based system for macromolecular structure solution. Acta Crystallogr D Biol Crystallogr 66:213221. CrossRef Medline

Altan-Bonnet N, Sougrat R, Liu W, Snapp EL, Ward T,Lippincott-Schwartz J (2006) Golgi inheritance in mammalian cells is mediated through endoplasmic reticulum export activities. Mol Biol Cell 17:990-1005. CrossRef Medline

Banci L, Bertini I, Ciofi-Baffoni S, Kozyreva T, Zovo K, Palumaa P (2010) Affinity gradients drive copper to cellular destinations. Nature 465:645648. CrossRef Medline
Battye TG, Kontogiannis L, Johnson O, Powell HR, Leslie AG (2011) iMOSFLM: a new graphical interface for diffraction-image processing with MOSFLM. Acta Crystallogr D Biol Crystallogr 67:271-281. CrossRef Medline

Baumgartner W, Hinterdorfer P, Ness W, Raab A, Vestweber D, Schindler H, Drenckhahn D (2000) Cadherin interaction probed by atomic force microscopy. Proc Natl Acad Sci U S A 97:4005-4010. CrossRef Medline

Baumkötter F, Wagner K, Eggert S, Wild K, Kins S (2012) Structural aspects and physiological consequences of APP/APLP trans-dimerization. Exp Brain Res 217:389-395. CrossRef Medline

Bayer TA, Schäfer S, Breyhan H, Wirths O, Treiber C, Multhaup G (2006) A vicious circle: role of oxidative stress, intraneuronal Abeta and $\mathrm{Cu}$ in Alzheimer's disease. Clin Neuropathol 25:163-171. Medline

Biederer T, Scheiffele P (2007) Mixed-culture assays for analyzing neuronal synapse formation. Nat Protoc 2:670-676. CrossRef Medline

Bolte S, Cordelières FP (2006) A guided tour into subcellular colocalization analysis in light microscopy. J Microsc 224:213-232. CrossRef Medline

Bush AI, Multhaup G, Moir RD, Williamson TG, Small DH, Rumble B, Pollwein P, Beyreuther K, Masters CL (1993) A novel zinc(II) binding site modulates the function of the beta A4 amyloid protein precursor of Alzheimer's disease. J Biol Chem 268:16109-16112. Medline

Chappuis-Flament S, Wong E, Hicks LD, Kay CM, Gumbiner BM (2001) Multiple cadherin extracellular repeats mediate homophilic binding and adhesion. J Cell Biol 154:231-243. CrossRef Medline

Chavda AP, Prole DL, Taylor CW (2013) A bead aggregation assay for detection of low-affinity protein-protein interactions reveals interactions between N-terminal domains of inositol 1,4,5-trisphosphate receptors. PLoS One 8:e60609. CrossRef Medline

Chen VB, Arendall WB 3rd, Headd JJ, Keedy DA, Immormino RM, Kapral GJ, Murray LW, Richardson JS, Richardson DC (2010) MolProbity: allatom structure validation for macromolecular crystallography. Acta Crystallogr D Biol Crystallogr 66:12-21. CrossRef Medline

Collaborative Computational Project, Number 4 (1994) The CCP4 suite: programs for protein crystallography. Acta Crystallogr D Biol Crystallogr 50:760-763. Medline

Dahms SO, Hoefgen S, Roeser D, Schlott B, Gührs KH, Than ME (2010) Structure and biochemical analysis of the heparin-induced E1 dimer of the amyloid precursor protein. Proc Natl Acad Sci U S A 107:5381-5386. CrossRef Medline

Dahms SO, Könnig I, Roeser D, Gührs KH, Mayer MC, Kaden D, Multhaup G, Than ME (2012) Metal binding dictates conformation and function of the amyloid precursor protein (APP) E2 domain. J Mol Biol 416:438452. CrossRef Medline

Duce JA, Tsatsanis A, Cater MA, James SA, Robb E, Wikhe K, Leong SL, Perez K, Johanssen T, Greenough MA, Cho HH, Galatis D, Moir RD, Masters CL, McLean C, Tanzi RE, Cappai R, Barnham KJ, Ciccotosto GD, Rogers JT, Bush AI (2010) Iron-export ferroxidase activity of beta-amyloid precursor protein is inhibited by zinc in Alzheimer's disease. Cell 142:857867. CrossRef Medline

Eggert S, Midthune B, Cottrell B, Koo EH (2009) Induced dimerization of the amyloid precursor protein (APP) leads to decreased amyloid-beta protein (Abeta) production. J Biol Chem 284:28943-28952. CrossRef Medline

Emsley P, Lohkamp B, Scott WG, Cowtan K (2010) Features and development of Coot. Acta Crystallogr D Biol Crystallogr 66:486-501. CrossRef Medline

Gaier ED, Eipper BA, Mains RE (2013) Copper signaling in the mammalian nervous system: synaptic effects. J Neurosci Res 91:2-19. CrossRef Medline

Galuska SP, Rollenhagen M, Kaup M, Eggers K, OltmannNorden I, Schiff M, Hartmann M, Weinhold B, Hildebrandt H, Geyer R, Mühlenhoff M, Geyer H (2010) Synaptic cell adhesion molecule SynCAM 1 is a target for polysialylation in postnatal mouse brain. Proc Natl Acad Sci U S A 107:10250-10255. CrossRef Medline

Graf ER, Zhang X, Jin SX, Linhoff MW, Craig AM (2004) Neurexins induce differentiation of GABA and glutamate postsynaptic specializations via neuroligins. Cell 119:1013-1026. CrossRef Medline

Gralle M, Oliveira CL, Guerreiro LH, McKinstry WJ, Galatis D, Masters CL, Cappai R, Parker MW, Ramos CH, Torriani I, Ferreira ST (2006) Solution conformation and heparin-induced dimerization of the full-length extracellular domain of the human amyloid precursor protein. J Mol Biol 357:493-508. CrossRef Medline

Hatcher LQ, Hong L, Bush WD, Carducci T, Simon JD (2008) Quantifica- 
tion of the binding constant of copper(II) to the amyloid-beta peptide. J Phys Chem B 112:8160-8164. CrossRef Medline

Hesse L, Beher D, Masters CL, Multhaup G (1994) The beta A4 amyloid precursor protein binding to copper. FEBS Lett 349:109-116. CrossRef Medline

Hong L, Bush WD, Hatcher LQ, Simon J (2008) Determining thermodynamic parameters from isothermal calorimetric isotherms of the binding of macromolecules to metal cations originally chelated by a weak ligand. J Phys Chem B 112:604-611. CrossRef Medline

Houtman JC, Brown PH, Bowden B, Yamaguchi H, Appella E, Samelson LE, Schuck P (2007) Studying multisite binary and ternary protein interactions by global analysis of isothermal titration calorimetry data in SEDPHAT: application to adaptor protein complexes in cell signaling. Protein Sci 16:30-42. CrossRef Medline

Isbert S, Wagner K, Eggert S, Schweitzer A, Multhaup G, Weggen S, Kins S, Pietrzik CU (2012) APP dimer formation is initiated in the endoplasmic reticulum and differs between APP isoforms. Cell Mol Life Sci 69:13531375. CrossRef Medline

Kaden D, Munter LM, Joshi M, Treiber C, Weise C, Bethge T, Voigt P, Schaefer M, Beyermann M, Reif B, Multhaup G (2008) Homophilic interactions of the amyloid precursor protein (APP) ectodomain are regulated by the loop region and affect beta-secretase cleavage of APP. J Biol Chem 283:7271-7279. CrossRef Medline

Kaden D, Munter LM, Reif B, Multhaup G (2012) The amyloid precursor protein and its homologues: structural and functional aspects of native and pathogenic oligomerization. Eur J Cell Biol 91:234-239. CrossRef Medline

Kardos J, Kovács I, Hajós F, Kálmán M, Simonyi M (1989) Nerve endings from rat brain tissue release copper upon depolarization. A possible role in regulating neuronal excitability. Neurosci Lett 103:139-144. CrossRef Medline

Keller S, Vargas C, Zhao H, Piszczek G, Brautigam CA, Schuck P (2012) High-precision isothermal titration calorimetry with automated peakshape analysis. Anal Chem 84:5066-5073. CrossRef Medline

Kemmer G, Keller S (2010) Nonlinear least-squares data fitting in Excel spreadsheets. Nat Protoc 5:267-281. CrossRef Medline

Kong GK, Adams JJ, Cappai R, Parker MW (2007a) Structure of Alzheimer's disease amyloid precursor protein copper-binding domain at atomic resolution. Acta Crystallogr Sect F Struct Biol Cryst Commun 63:819-824. CrossRef Medline

Kong GK, Adams JJ, Harris HH, Boas JF, Curtain CC, Galatis D, Masters CL, Barnham KJ, McKinstry WJ, Cappai R, Parker MW (2007b) Structural studies of the Alzheimer's amyloid precursor protein copper-binding domain reveal how it binds copper ions. J Mol Biol 367:148-161. CrossRef Medline

Kong GK, Miles LA, Crespi GA, Morton CJ, Ng HL, Barnham KJ, McKinstry WJ, Cappai R, Parker MW (2008) Copper binding to the Alzheimer's disease amyloid precursor protein. Eur Biophys J 37:269-279. CrossRef Medline

Lambert M, Padilla F, Mège RM (2000) Immobilized dimers of $\mathrm{N}$-cadherin-Fc chimera mimic cadherin-mediated cell contact formation: contribution of both outside-in and inside-out signals. J Cell Sci 113:2207-2219. Medline

Lee S, Xue Y, Hu J, Wang Y, Liu X, Demeler B, Ha Y (2011) The E2 domains of APP and APLP1 share a conserved mode of dimerization. Biochemistry 50:5453-5464. CrossRef Medline

Lutsenko S, Bhattacharjee A, Hubbard AL (2010) Copper handling machinery of the brain. Metallomics 2:596-608. CrossRef Medline

Martell A, RM Smith, Motekaitis R (2004) NIST critically selected stability constants of metal complexes. In: NIST Standard Reference Database 46, version 80. College Station, TX; National Institute of Standards and Technology.

Masters CL, Beyreuther K (2006) Alzheimer's centennial legacy: prospects for rational therapeutic intervention targeting the Abeta amyloid pathway. Brain 129:2823-2839. CrossRef Medline

Maynard CJ, Cappai R, Volitakis I, Cherny RA, White AR, Beyreuther K, Masters CL, Bush AI, Li QX (2002) Overexpression of Alzheimer's dis- ease amyloid-beta opposes the age-dependent elevations of brain copper and iron. J Biol Chem 277:44670-44676. CrossRef Medline

McCoy AJ, Grosse-Kunstleve RW, Adams PD, Winn MD, Storoni LC, Read RJ (2007) Phaser crystallographic software. J Appl Crystallogr 40:658 674. CrossRef Medline

Müller UC, Zheng H (2012) Physiological functions of APP family proteins. Cold Spring Harb Perspect Med 2:a006288. CrossRef Medline

Multhaup G, Schlicksupp A, Hesse L, Beher D, Ruppert T, Masters CL, Beyreuther K (1996) The amyloid precursor protein of Alzheimer's disease in the reduction of copper(II) to copper(I). Science 271:1406-1409. CrossRef Medline

Noda Y, Asada M, Kubota M, Maesako M, Watanabe K, Uemura M, Kihara T, Shimohama S, Takahashi R, Kinoshita A, Uemura K (2013) Copper enhances APP dimerization and promotes Abeta production. Neurosci Lett 547:10-15. CrossRef Medline

Putnam CD, Hammel M, Hura GL, Tainer JA (2007) X-ray solution scattering (SAXS) combined with crystallography and computation: defining accurate macromolecular structures, conformations and assemblies in solution. Q Rev Biophys 40:191-285. CrossRef Medline

Roberts BR, Ryan TM, Bush AI, Masters CL, Duce JA (2012) The role of metallobiology and amyloid-beta peptides in Alzheimer's disease. J Neurochem 120 [Suppl 1]:149-166. CrossRef

Rossjohn J, Cappai R, Feil SC, Henry A, McKinstry WJ, Galatis D, Hesse L, Multhaup G, Beyreuther K, Masters CL, Parker MW (1999) Crystal structure of the N-terminal, growth factor-like domain of Alzheimer amyloid precursor protein. Nat Struct Biol 6:327-331. CrossRef Medline

Sato T, Tang TC, Reubins G, Fei JZ, Fujimoto T, Kienlen-Campard P, Constantinescu SN, Octave JN, Aimoto S, Smith SO (2009) A helix-to-coil transition at the epsilon-cut site in the transmembrane dimer of the amyloid precursor protein is required for proteolysis. Proc Natl Acad Sci U S A 106:1421-1426. CrossRef Medline

Scheiffele P, Fan J, Choih J, Fetter R, Serafini T (2000) Neuroligin expressed in nonneuronal cells triggers presynaptic development in contacting axons. Cell 101:657-669. CrossRef Medline

Schmidt V, Baum K, Lao A, Rateitschak K, Schmitz Y, Teichmann A, Wiesner B, Petersen CM, Nykjaer A, Wolf J, Wolkenhauer O, Willnow TE (2012) Quantitative modelling of amyloidogenic processing and its influence by SORLA in Alzheimer's disease. EMBO J 31:187-200. CrossRef Medline

Siddiqui TJ, Craig AM (2011) Synaptic organizing complexes. Curr Opin Neurobiol 21:132-143. CrossRef Medline

Smith DG, Cappai R, Barnham KJ (2007) The redox chemistry of the Alzheimer's disease amyloid beta peptide. Biochim Biophys Acta 1768:19761990. CrossRef Medline

Soba P, Eggert S, Wagner K, Zentgraf H, Siehl K, Kreger S, Löwer A, Langer A, Merdes G, Paro R, Masters CL, Müller U, Kins S, Beyreuther K (2005) Homo- and heterodimerization of APP family members promotes intercellular adhesion. EMBO J 24:3624-3634. CrossRef Medline

Spoerri L, Vella LJ, Pham CL, Barnham KJ, Cappai R (2012) The amyloid precursor protein copper binding domain histidine residues 149 and 151 mediate APP stability and metabolism. J Biol Chem 287:26840-26853. CrossRef Medline

Svergun DI (1999) Restoring low resolution structure of biological macromolecules from solution scattering using simulated annealing. Biophys J 76:2879-2886. CrossRef Medline

Tamano H, Takeda A (2011) Dynamic action of neurometals at the synapse. Metallomics 3:656-661. CrossRef Medline

Wang Y, Ha Y (2004) The X-ray structure of an antiparallel dimer of the human amyloid precursor protein E2 domain. Mol Cell 15:343-353. CrossRef Medline

Wang Z, Wang B, Yang L, Guo Q, Aithmitti N, Songyang Z, Zheng H (2009) Presynaptic and postsynaptic interaction of the amyloid precursor protein promotes peripheral and central synaptogenesis. J Neurosci 29: 10788-10801. CrossRef Medline

White AR, Multhaup G, Maher F, Bellingham S, Camakaris J, Zheng H, Bush AI, Beyreuther K, Masters CL, Cappai R (1999) The Alzheimer's disease amyloid precursor protein modulates copper-induced toxicity and oxidative stress in primary neuronal cultures. J Neurosci 19:9170-9179. Medline 